\title{
An assessment of geomorphometric anomalies and their significance on the seismotectonic activity through geoinformatics
}

\author{
Snehasish Ghosh ${ }^{1,2, *}$ (D) and R Sivakumar ${ }^{1,2}$ \\ ${ }^{1}$ Earthquake Research Cell, Faculty of Engineering and Technology, SRM Institute of Science and Technology, \\ Kattankulathur, Kancheepuram District, Tamil Nadu, India. \\ ${ }^{2}$ Department of Civil Engineering, Faculty of Engineering and Technology, SRM Institute of Science and \\ Technology, Kattankulathur, Kancheepuram District, Tamil Nadu, India. \\ *Corresponding author. e-mail: snehasishghosh.s@ktr.srmuniv.ac.inｓnehasishghosh.s10@gmail.com
}

MS received 21 February 2018; revised 9 January 2019; accepted 22 February 2019; published online 24 June 2019

The natural system of the drainage basin is interrupted by sub-surface faults and active tectonic processes. The anomalous nature of the drainage network and its basic morphological characteristics produce significant geomorphometric anomalies of the drainage basins which are an indicator of seismotectonic activity. In recent years, the increasing frequency of earthquakes and the subsequent damage in the Indian sub-continent necessitates a study of the seismotectonic significance with special reference to morphometric analysis. Hence, the present research is focused on studying the geomorphometric anomalies at a micro basin level and their impact on seismotectonic activity using geoinformatics. The study area is the lower Tista sub-basin which belongs to the Himalayan mountain in the northern part, whereas the southern part represents a peneplain surface. The quantitative databases of various morphometric parameters have been generated using digital elevation model data and satellite images to identify the geomorphic anomalies at the micro basin level which have been compared with past seismological databases to understand the impact on seismotectonic activity. The result shows that the drainage bifurcation, anomalous drainage network, drainage compression along the mountain front, narrow steep valleys in the high resistance surface, neotectonic deformation and the asymmetric valley shape are probable geomorphometric anomalies which coincide with past seismic activity in the study region. The present study also shows that the tectonic tilt, compressed meanders in the uplifted surface and the linear valley in the alluvial surface are also equivalently significant for past earthquake occurrences in the foothill zone. It is also observed that the elongated and linear micro basins and the presence of a strike-slip fault with major lineaments in the Quaternary surface are great indicators of geomorphometric anomalies which have no resemblance with any significant earthquake in the past and are equally important signatures of seismotectonic activity. The study concludes that the geomorphometric anomaly is an important parameter of seismotectonic activity which can be used for studying seismic hazards in the future.

Keywords. Geomorphometric anomaly; active tectonics; seismotectonic activity; geoinformatics.

\section{Introduction}

Morphometry is a fundamental element of fluvial geomorphology which studies the interaction between fluvial processes and landform dynamics by analysing the form and function of streams (Chorley 1969; Prabu and Baskaran 2013). Drainage morphometry is defined as the mathematical 
analysis and quantitative measurement of length, area, perimeter, shape, volume and altitude of a drainage basin for evaluating the geomorphic landforms (Clarke 1970; Keller and Pinter 2002). It explains the morphological changes which occur during the long-term evolution process of a drainage basin that can significantly impact landscape dynamics (Bali et al. 2012). Fluvial morphometry involves studying the drainage basin properties and the stream evolution process by estimating the morphometric parameters (Ozdemir and Bird 2009; Prabu and Baskaran 2013). Drainage networks and its basin configurations are the key elements of morphometric analysis (Abrahams 1984). The analysis of morphometric parameters recognises the geomorphic characteristics and landscape evolution processes in a drainage basin (Singh 2005). The evolution of landscape in a drainage basin depends on the erosional power of streams and the resistance capacity of the topographic surface which depends on the sub-surface geology and lithological characteristics (Zavoianu 1985). The surface drainage and its morphometric properties are determined by the sub-surface structural, tectonic and geological characteristics (Cox 1994; Perez-Pena et al. 2010). The analysis of morphometric parameters evaluates the relationship between tectonic geomorphology and the landscape dynamic process (Reddy et al. 2004).

Active tectonics is a significant parameter of tectonic geomorphology for the investigation of the fluvial geomorphic process in a river basin (Tsodulos et al. 2008). The anomaly in the fluvial geomorphic process indicates the tectonic deformation and the structural influence of landscape evolution on the Earth's crust which can be analysed using drainage morphometric parameters (Keller and Pinter 2002). Several research studies have been carried out to investigate the geomorphic anomaly by analysing the morphometric parameters. Viveen et al. (2012) evaluated the geomorphic anomaly in the lower Mino catchment in NW Iberia and concluded that the asymmetric nature of the basin, incised river valley, upliftment process and basin subsidence indicates recent tectonic movement. Cuong and Zuchiewicz (2001) analysed morphotectonic parameters to study the geomorphic anomaly in the Lo river basin in North Vietnam and identified that the presence of resistance rocks, a narrow valley and an elongated basin are the indicators of tectonic activity. The estimation of morphometric parameters of the Ramganga drainage basin in Uttarakhand indicated that the morphological characteristics of drainage basins and the structural control of the drainage network are influenced by tectonic activity (Asthana et al. 2015). Musumeci et al. (2003) discussed the effects of tectonics on the drainage morphological anomaly in Argentera Massif Western Alps, Italy and suggested that the differential denudation process, anomalous drainage network, etc. are responsible for long-term changes of the landscape and uplift processes. Altin (2012) analysed various morphometric indices in the southern Bolkar mountain region and concluded that a stream length gradient anomaly, a steeped narrow valley, an elongated basin and a primary stage in a drainage network indicate greater tectonic activity. Mahmood and Gloaguen (2012) analysed geomorphic indices and drainage patterns to identify the geomorphic anomaly in the Hindu Kush region and observed that the high rate of upliftments, deformed landforms and anomalous drainage patterns are responsible for active tectonics. The analysis of various morphometric parameters in the south-west border of the Sierra Nevada (southern Spain) suggested that the tilted basin, lithological resistance and young geomorphic landforms are indicators of tectonic activity and geomorphic anomalies (El Hamdouni et al. 2008). Venkatesan et al. (2015) quantified various geomorphic parameters in the Thoppaiyar sub-basin to study the significance of drainage morphological parameters of geomorphic anomalies and the study confirmed that the high resistance surface in the elevated region, young topography, tectonic tilt and river migration are indicators of high tectonic activity. The evaluation of linear areal and relief morphotectonic parameters in the Alaknanda river basin identified that drainage bifurcation, relief dissection and structural anomalies are significant evidences of tectonic activity (Shukla et al. 2014). The analysis of stream length gradient anomaly and sinuosity index in North Canterbury, New Zealand reveals that the fold, fault and lineaments have greater control on the development of the channel pattern in high- and low-resistance surfaces (Litchfield et al. 2003). Hassen et al. (2014) discussed relevant morphometric parameters to study the recent geomorphic anomalies along the Gafsa fault in the Southern Atlas of Tunisia which suggest that the heterogeneous land surface, drainage anomalies, vertical curvature and undulating rough topography signify long-term morphodynamic changes in the landscape. The drainage morphometric analysis of linear, areal and relief parameters of drainage 
basins identifies that the drainage anomaly, asymmetric basin, structural control of the drainage network, high rate of denudation and weathering process, resistance topography and young geomorphic features are indicators of seismotectonic activity in a particular region (Mahmood and Gloaguen 2012; Bahrami 2013; Venkatesan et al. 2015).

Active seismotectonic zones are recognised along the active fault which is marked as frequent earthquake occurrences with significant magnitude. It is formed due to the displacements of structural features and deformation of rock masses (Kuk et al. 2000). The analysis of drainage morphometric parameters and identification of geomorphic anomaly are key to seismotectonic studies (John and Rajendran 2008; Singh et al. 2016). Silva et al. (2003) studied the geomorphic indices for the assessment of tectonic and seismic activities in Spain which showed that the variation of geomorphic anomalies such as upliftment, discrete surface rupture, etc., determine the active tectonic process and seismic activity. John and Rajendran (2008) discussed about the various geomorphic indicators of neotectonism in peninsular India and suggested that the abandoned river channels, geomorphic anomalies and seismotectonic fault are associated with earthquakes and active tectonics. A comparative study of the morphometric parameters with seismic activity showed that the tectonic tilt, high deformation activity produces folded structures which are responsible for earthquakes and seismotectonic activity in the Jia Bhareli river catchment in the eastern Himalaya (Duarah and Phukan 2011). A study of the geomorphic observations and their tectonic implications reveals that the anomalies in the morphometric parameters correspond to lineaments, faults and micro seismic activities of the Palghat gap in south India (Singh et al. 2016). Bhattacharya et al. (2013) investigated the morphometric evidences of seismic activity in the Wagad and Gedi faults, Eastern Kachchh, Gujarat by analysing various morphometric parameters which reveal that the asymmetric nature of basin and stream migration suggests lateral displacements of faults, tectonic instability and seismic activity. Also, drainage morphometric study and its integration with seismic data show that basin tilt and channel incision are responsible for the seismotectonic activity in the Brahmaputra river basin (Sarma et al. 2015).

Geoinformatics plays a significant role in drainage morphological studies because it maintains a large volume of databases and has the capability to integrate several geospatial databases (Lo and Yeung 2007; Bhatta 2008). The quantification of morphometric parameters can be derived from topographic maps, digital elevation model (DEM) data, aerial photographs, satellite imagery and fieldwork (Keller and Pinter 2002; Venkatesan et al. 2015). The morphometric parameters have been extracted from the topographical map and field observation data as a traditional method in Acambay graben, Mexico (Ramírez-Herrera 1998). Similarly, an aerial photograph was used with the incorporation of field observation data in southeast Spain for a drainage morphometric study (Silva et al. 2003). Furthermore, DEM and multispectral satellite images have been used for the morphometric analysis in the inter-fluvial tract of Punjab, NW India (Bhatt et al. 2008), the Hindu Kush region (Mahmood and Gloaguen 2012), the Alaknanda river basin (Shukla et al. 2014) and the Thamirabarani sub-basin in Kanyakumari district (Kaliraj et al. 2015).

The Himalayan region and the Quaternary geological surface of the Indian sub-continent had experienced several earthquakes in recent geological periods due to tectonic activity (Verma and Bansal 2013). Since then, scientists have studied seismic hazards by developing several models with special reference to seismic waves, site investigation, attenuation characteristics and geophysical properties, whereas less attention has been given to active tectonics and drainage morphological parameters (Bansal and Vandana 2007; Nath et al. 2007; Anbazhagan and Sitharam 2008; Pal et al. 2008). The above literature studies depict that the drainage pattern and its segmentation, basin geometric form, intensity of drainage dissection, symmetric and asymmetric nature of the drainage basin and influence of relief characteristics have a greater impact on tectonics and seismic activity. Thus, it requires a study of the morphometric parameters for identifying the geomorphometric anomaly. Hence, the present research focuses on the quantification of various morphometric parameters for the assessment of geomorphometric anomaly and its significance on seismotectonic activity using geoinformatics.

\section{Study area}

The study area is the lower Tista sub-basin which is a part of the Brahmaputra basin, with a latitudinal 


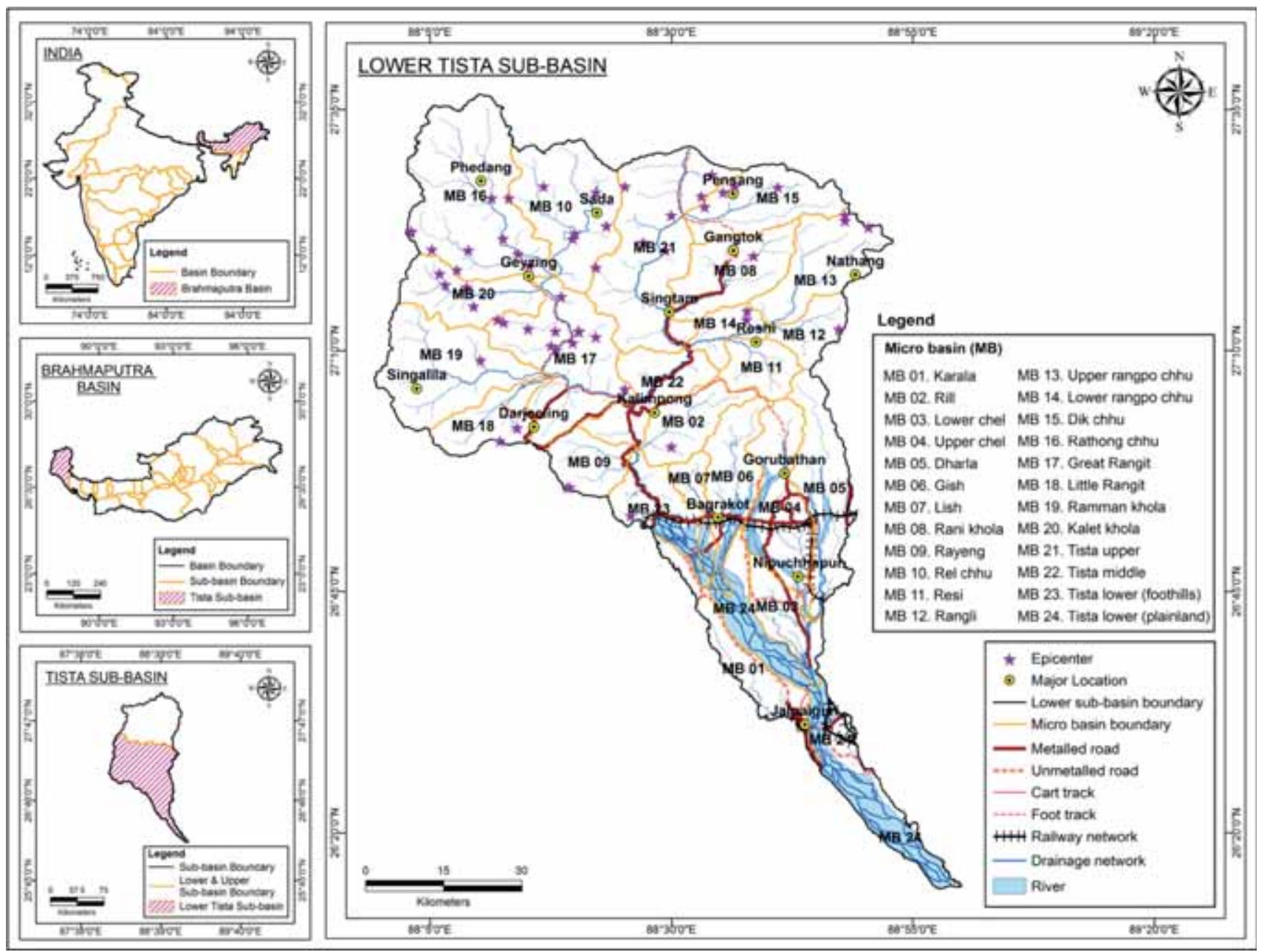

Figure 1. Location map of study area.

extension from $27^{\circ} 20^{\prime}$ to $27^{\circ} 35^{\prime} \mathrm{N}$ and longitudinal extension from $88^{\circ} 05^{\prime}$ to $88^{\circ} 20^{\prime} \mathrm{E}$. It has an area of $6043.71 \mathrm{~km}^{2}$ approximately which is bounded by the upper Tista sub-basin in the north, the Torsa basin in the east, the lower part of the Tista basin in the south and the Mechi basin in the west (figure 1). Tista is the major river in the study area which flows towards the south and the south-west direction and meets various tributaries. It produces a narrow steep valley in the upper course due to the presence of crystalline hard rocks, whereas in the lower part, it shows a much wider valley in the alluvial low resistance surface. The tributaries in the upper course are Rangit, Dik chhu, Rani Khola, and the rill, Rathong chhu while Gish, Lish, Chel and Dharla are the major tributaries in the lower course. The study area has been divided into 24 micro basins on the basis of the major segmentation of the drainage network which have been derived from CARTOSAT DEM and satellite image as shown in figure $2(\mathrm{a}$ and $\mathrm{b})$. From a broad geological point of view, the region is extended from quaternary sediments to the Greater Himalayan sequence from the south to the north which has been segmented by the fold thrust movement. Physiographically, it belongs to a part of the Himalayan mountain in the northern part which is characterised by very steep slopes with escarpments, narrow valley and ridges, whereas the southern part of the study region represents the peneplain surface with a gentle slope topography. The major places of the study area are Nathang, Gogong, Gezing, Kalimpong, Reshi and Darjeeling in the mountainous region and Bagrakot, Gorubathan, Nipuchhapur and Jalpaiguri are the major locations in the peneplain surface.

\section{Methodology}

The study has been conducted in five stages as shown in the flow chart (figure 3). In the first stage, spatial as well as non-spatial data have been collected from different sources and have 


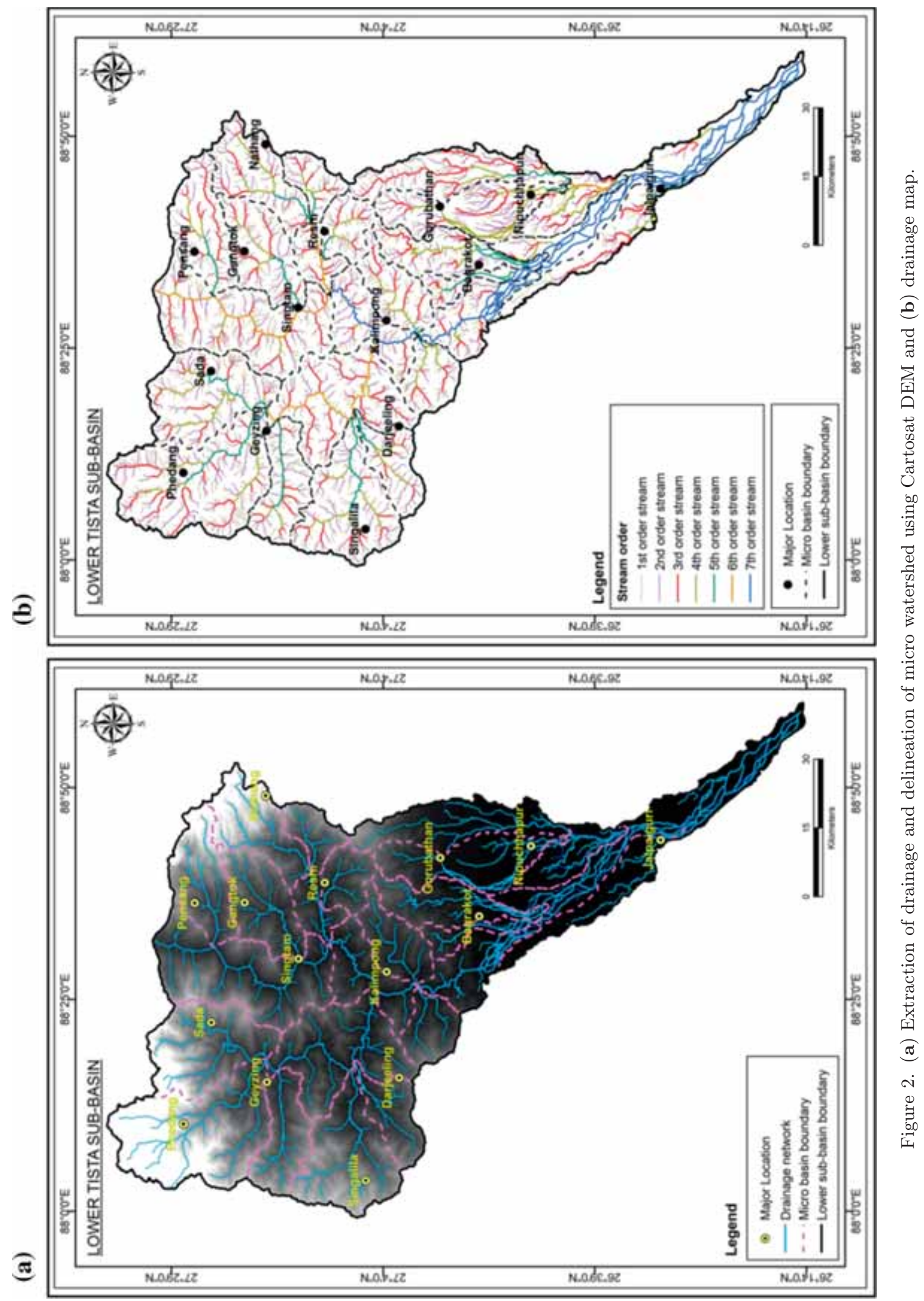




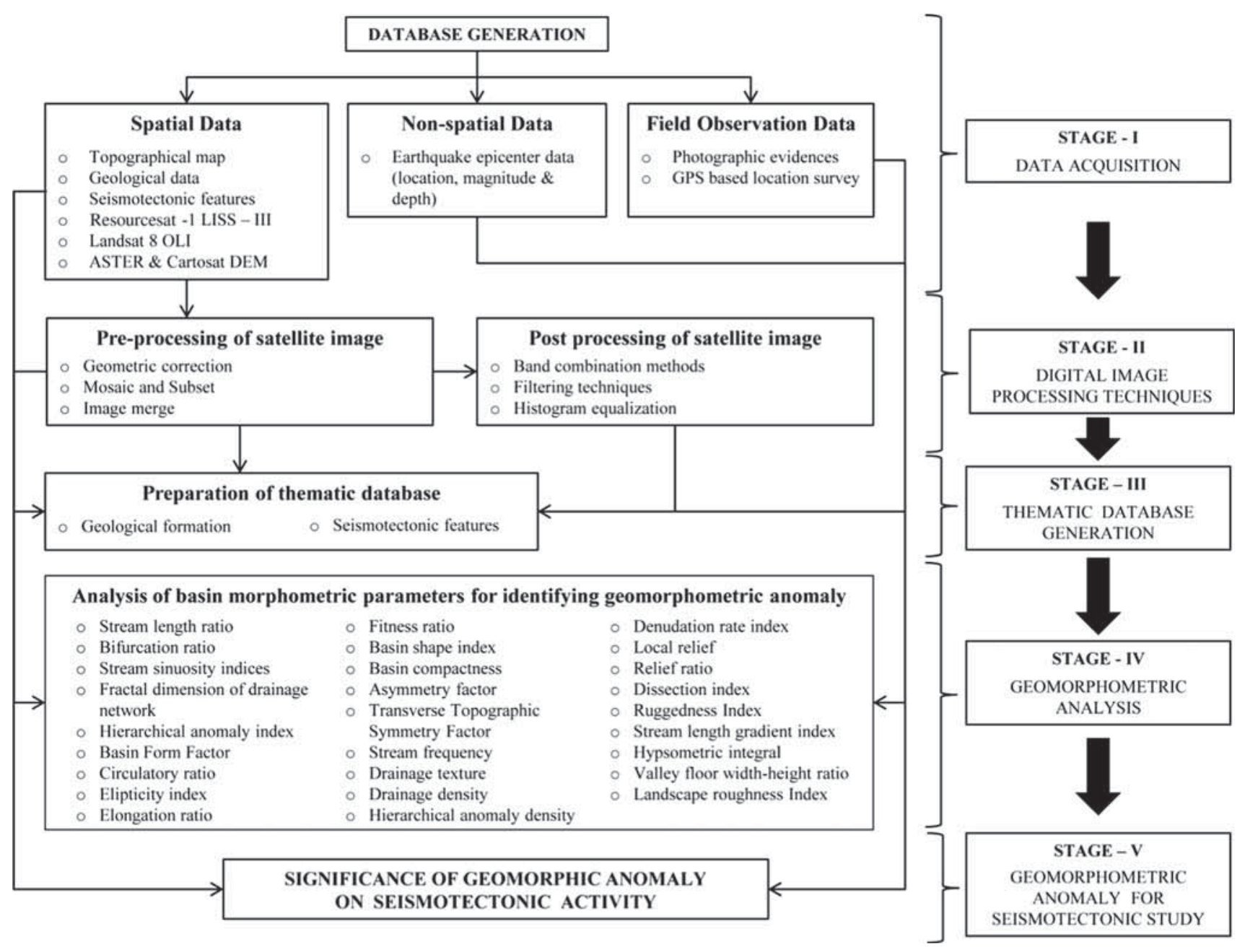

Figure 3. Flow chart of methodology.

also been incorporated with field observation data for further analysis. In the second stage, digital image processing techniques have been applied to prepare the image for analysis and geodatabase generation. In the third stage, GIS-based specific thematic databases such as geological formations and seismotectonic features have been prepared using spatial and non-spatial data accompanied by limited field observation. In the fourth stage, quantitative databases have been generated for different drainage morphometric parameters and suitable diagrams have been prepared for a comparative analysis of the parameters. Finally, all morphometric parameters have been integrated with past seismological databases for an assessment of their significance on seismotectonic activity.

\subsection{Data acquisition}

In the present study, the spatial and non-spatial data have been collected from different governmental and non-governmental sources for the preparation of geodatabases and drainage morphometric analysis. The Survey of India (SOI) topographical map is used as a database to rectify other spatial databases through the geo-referencing process in GIS. The spatial information on geology has been collected from the Geological Survey of India (GSI) portal map services and updated with limited field observation data. Also, the seismotectonic atlas has been referred to for tectonic feature identification. ASTER GDEM of 2011 has been collected from the United States Geological Survey (USGS) earth explorer to extract elevation information while CARTOSAT DEM of 2011 has been obtained from the National Remote Sensing Centre India (NRSC), Bhuvan, the Indian Geo-portal of ISRO Open data archive to extract surface drainage for morphometric analysis. In addition, Landsat 8-OLI and Resourcesat-1 LISS III satellite images have been acquired from the USGS and the NRSC, respectively, to update the Cartostat DEM-derived drainage network. The attributed data of earthquake epicentres, mainly 
Table 1. Data used and sources.

\begin{tabular}{|c|c|c|c|}
\hline Data used & $\begin{array}{l}\text { Year/ } \\
\text { month }\end{array}$ & $\begin{array}{l}\text { Scale/resolution in } \\
\text { metres/pixel }(\mathrm{m} / \mathrm{p})\end{array}$ & Source of data \\
\hline $\begin{array}{l}\text { Topographical map } 78 \mathrm{~A} \\
\text { and } 78 \mathrm{~B}\end{array}$ & 1937 & $1: 253,440$ & Survey of India \\
\hline Geological map of Sikkim & 2012 & $1: 500,000$ & $\begin{array}{l}\text { Geological Survey of India, Miscellaneous } \\
\text { Publication No. 30, GSI portal map } \\
\text { services/state geology and maps } \\
\text { (Mukherjee and Sharma 2013) }\end{array}$ \\
\hline $\begin{array}{l}\text { Geological map of West } \\
\text { Bengal }\end{array}$ & 2010 & $1: 2,000,000$ & $\begin{array}{l}\text { Geological Survey of India, Miscellaneous } \\
\text { Publication No. 30, GSI portal map } \\
\text { services/state geology and maps } \\
\text { (Sarkar et al. 2012) }\end{array}$ \\
\hline $\begin{array}{l}\text { Seismotectonic atlas of } \\
\text { India and its environment } \\
\text { SEISAT-13 Map }\end{array}$ & 2000 & $1: 1,000,000$ & $\begin{array}{l}\text { Geological Survey of India (Dasgupta et al. } \\
2000 \text { ) }\end{array}$ \\
\hline Resourcesat 1-LISS-III & 2011 & $23 \mathrm{~m} / \mathrm{p}$ & $\begin{array}{l}\text { NRSC, India, Bhuvan, Indian Geoportal of } \\
\text { ISRO, Open data archive }\end{array}$ \\
\hline Landsat 8-OLI & 2015 & $30 \mathrm{~m} / \mathrm{p}$ & USGS Earth explorer \\
\hline Cartosat DEM & 2011 & $30 \mathrm{~m} / \mathrm{p}$ & $\begin{array}{l}\text { NRSC, India, Bhuvan, Indian Geoportal of } \\
\text { ISRO, Open data archive }\end{array}$ \\
\hline ASTER GDEM & 2011 & $30 \mathrm{~m} / \mathrm{p}$ & USGS Earth explorer \\
\hline Seismological data & $1964-2015$ & - & $\begin{array}{l}\text { Earthquake catalogue of India, earthquake } \\
\text { catalogue in and around the north-eastern } \\
\text { region of India, USGS and IMD, etc. }\end{array}$ \\
\hline Field observation data & 2016 & - & Field visit \\
\hline
\end{tabular}

the epicentre location and magnitude, have been acquired for the period between 1964 and 2015 from various published seismological catalogues such as the earthquake catalogue of India, earthquake catalogue in and around the north-eastern region of India, the USGS and the Indian Meteorological Department (IMD), National Centre for Seismology, Ministry of Earth Sciences (MOES). The GPS-based location survey and photographic evidences of active tectonics have been collected during the field study (table 1).

\subsection{Digital image processing}

In the present study, both pre- and post-digital image processing techniques have been applied before geodatabase generation. The pre-processing of the image includes geometric correction, mosaic, image merging and subset which help in preparing the image for analysis. The post-processing process includes band combination, filtering and histogram equalisation which help in enhancing the image for better interpretation. The topographical map has been georeferenced as per existing coordinates and used as a base map for the rectification of satellite images through image-to-image georeferencing techniques. To delineate the study area boundary, the selected satellite images have been mosaicked and the area of interest has been extracted through the subset option. Also, the image has been merged with PAN data to obtain a better resolution. In the case of post-processing, various false colour composite (FCC) band combination methods have been applied to identify the drainage network and geomorphic landforms. Edge detection filtering techniques (Sobel filtering) are used to extract the structural features. Furthermore, histogram equalisation techniques are applied for nonlinear contrast enhancement to identify the anomalous geomorphometric signatures.

\subsection{Thematic database generation}

\subsubsection{Geological formation}

The geodatabase on the geological formation has been prepared using the geological maps of Sikkim and West Bengal (Sarkar et al. 2012; Mukherjee and Sharma 2013) and updated with limited field work. The study area is divided into various geological formations on the basis of a broad geological unit and is shown in figure 4(a) and table 2 . 


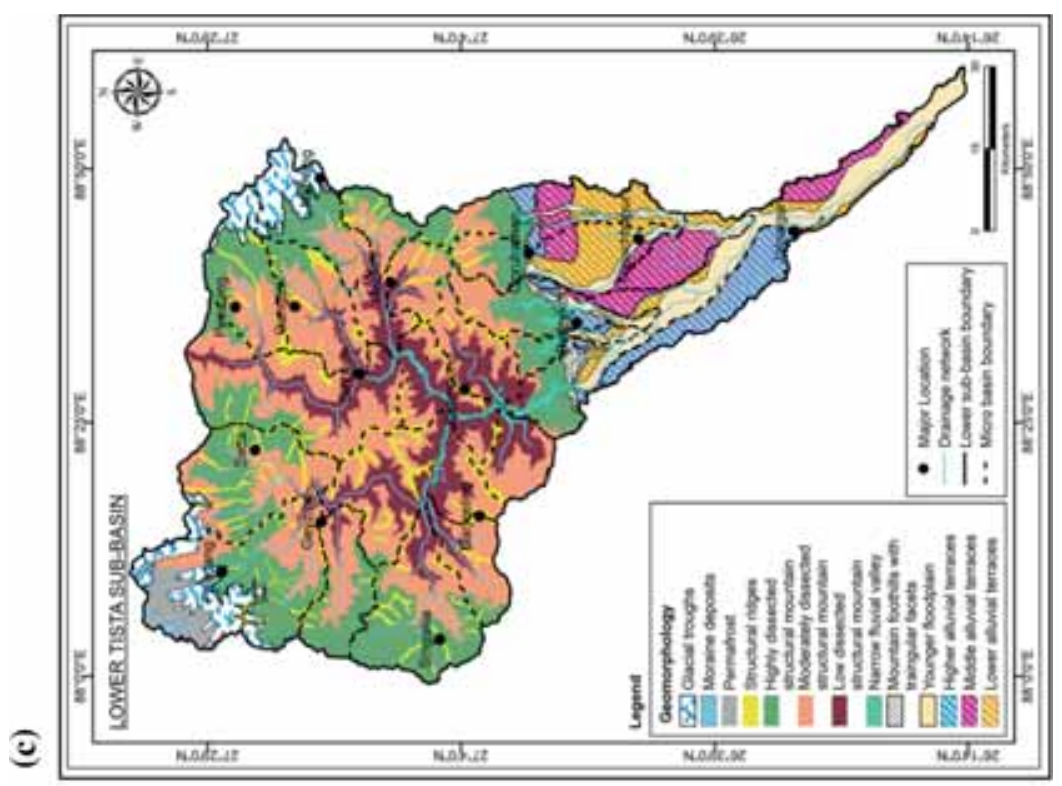

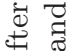

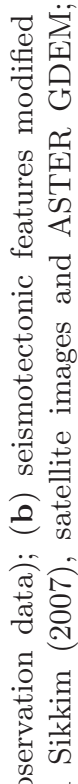

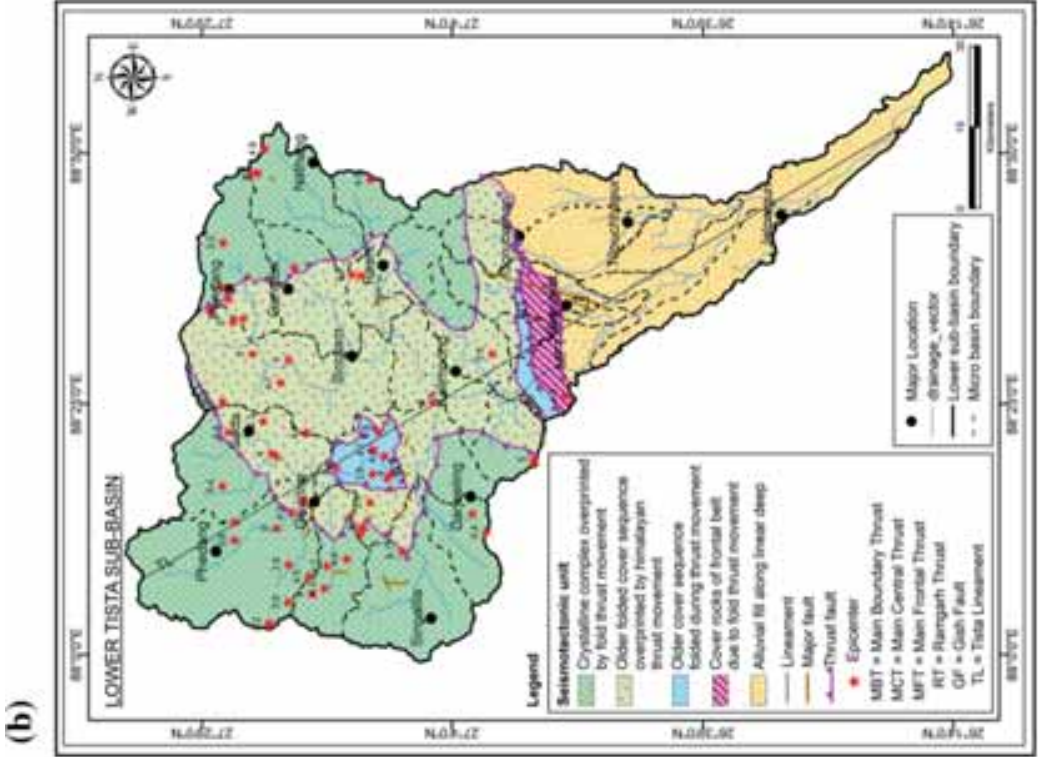

ก․

류)

总要

듄

㟧

तิ

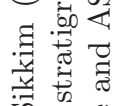

㞤

嗀

సే

웅

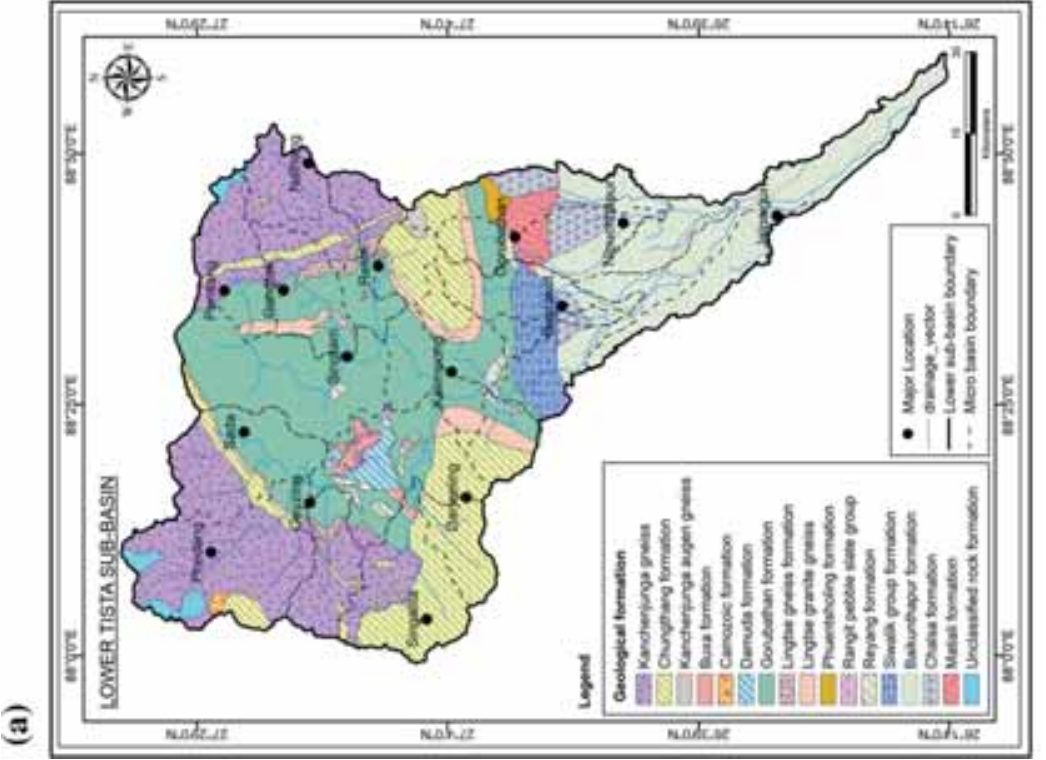

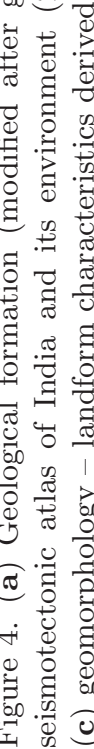


Table 2. Broad geological units and their various formations.

\begin{tabular}{|c|c|c|c|}
\hline $\begin{array}{l}\text { Broad geological } \\
\text { class }\end{array}$ & Geological formation & Lithological type & Micro basin region \\
\hline $\begin{array}{l}\text { A. Greater Himalayan } \\
\text { sequence }\end{array}$ & $\begin{array}{l}\text { 1. Kanchenjunga gneiss } \\
\text { formation } \\
\text { 2. Chungthang formation } \\
\text { 3. Kanchenjunga augen } \\
\text { gneiss formation } \\
\text { 4. Cainozoic formation }\end{array}$ & $\begin{array}{l}\text { Biotite gneiss, Sillimanite } \\
\text { Granite gneiss, Magnetite, } \\
\text { Kyanite and Mica schist }\end{array}$ & $\begin{array}{l}\text { Kalet khola, Rathong chhu, } \\
\text { Rel chhu, Ramman khola } \\
\text { Little rangit, Ramman } \\
\text { khola, Rangpo chhu }\end{array}$ \\
\hline $\begin{array}{l}\text { B. Lesser Himalayan } \\
\text { sequence }\end{array}$ & $\begin{array}{l}\text { 1. Gorubathan formation } \\
\text { 2. Buxa formation } \\
\text { 3. Damuda formation } \\
\text { 4. Reyang formation } \\
\text { 5. Ranjit pebble slate group } \\
\text { 6. Lingtse gneiss formation } \\
\text { 7. Lingtse granite gneiss } \\
\quad \text { formation } \\
\text { 8. Phuentsholling formation }\end{array}$ & $\begin{array}{l}\text { Chlorite, Schist, Phyllite, } \\
\text { Quartzite, Dolomite } \\
\text { Sandstone, Shale and } \\
\text { Carboniferous shale }\end{array}$ & $\begin{array}{l}\text { Tista upper, middle micro } \\
\text { basin, Great rangit micro } \\
\text { basin, Dik chhu, Rani khola }\end{array}$ \\
\hline C. Siwalik sequence & $\begin{array}{l}\text { 1. Siwalik group of } \\
\text { formations }\end{array}$ & $\begin{array}{l}\text { Sandstone, Conglomerate, } \\
\text { Shales }\end{array}$ & $\begin{array}{l}\text { Lower Tista (foothills), Gish } \\
\text { and Lish micro basin }\end{array}$ \\
\hline D. Quaternary sequence & $\begin{array}{l}\text { 1. Baikunthapur formation } \\
\text { 2. Chalsa formation } \\
\text { 3. Matiali formation }\end{array}$ & $\begin{array}{l}\text { Boulders, Gravels, Pebbles, } \\
\text { Sands and Silts }\end{array}$ & $\begin{array}{l}\text { Lower chel, Dharla, Lish } \\
\text { Gish and Upper chel }\end{array}$ \\
\hline
\end{tabular}

The Greater Himalayan sequence is the outermost part of the study area above the main central thrust (MCT) which comprises mainly hard crystalline rocks. The Lesser Himalayan sequence is affected by numerous fold thrust movements which consist of soft sedimentary and metamorphic rocks. In the Greater Himalayan sequence, the Kanchenjunga gneiss and Chungthang are two major formations, whereas in the Lesser Himalayan sequence, the Gorubathan formation is dominant. The Siwalik group of formations is evolved by the sequential erosion and deposition of fluvial action in the area between the frontal and boundary thrusts. The rocks are folded and faulted by lateral compressions to produce the Siwalik foothills. The Baikunthapur formation, Chalsa formation and Matiali formation are the quaternary group of formations which are very recent and a younger formation and are composed of sand, silt and clay (Mukherjee and Sharma 2013).

\subsubsection{Seismotectonic characteristics}

The origin of the tectonic framework of the Himalaya and the adjacent orogenic belt is the result of different tectonic activation and reactivation in the geological past. Such activities in the regional extent formed their distinctive tectonic-stratigraphic characters associated with folding, faulting and lineament features (McCann and Saintot 2003). The evolution of the seismotectonic features in different geological ages forms the Himalaya and adjacent orogenic belts, with numerous fragmented rocks (Bansal and Nath 2011).

The seismotectonic database has been prepared using the seismotectonic atlas of India and updated using Landsat Satellite data, ASTER DEM with limited field observation (figure 4b). The structural features have been extracted from the satellite image with the incorporation of digital image processing techniques which include band combination methods, filtering techniques, histogram equalisation, etc. The region is divided into five seismotectonic zones by the separation of the sequential thrust, namely, the main frontal thrust (MFT), main boundary thrust (MBT), main central thrust (MCT) and Ramghar thrust (RT) (Dasgupta et al. 2000, 2013; Grujic et al. 2002; Mukul et al. 2014). A crystalline complex overprinted by a fold thrust movement seismotectonic unit is observed outside the MCT which covers the upper part of the Rathong chhu, Rel chhu, Kalet 
khola, Ramman khola, Little rangit, Dik chhu, Rani khola, Upper Rangpo chhu, Rayeng, Resi and Rangali micro basins. An older folded cover sequence overprinted by the Himalayan thrust movement which is surrounded by the MCT zone covers the maximum portion of the Tista upper and the Tista middle micro basins. Also, a significant portion of this unit has been observed in the lower catchment area of Rell chhu, Klalet khola, Rathong chhu, Dik chhu, Rani khola, Raying, the upper part of Lish and the middle portion of the Gish, Chel and Dharla micro basin area. An older cover sequence folded during the thrust movement is observed inside the Ramgarh thrust (RT) zone which has been enclosed in the Great Rangit micro basin. Also, a portion of this tectonic unit has been recognised in the upper part of Lish, Tista lower (foothills) and the middle portion of the Gish micro basin area. Cover rocks of the frontal belt due to the fold thrust movement have been traced between the MFT and the MBT, including the middle portion of the Lish, Tista lower (foothills) and Gish micro basin areas. Alluvial fill along a linear deep tectonic unit is extended below MFT, covering the micro basin of Karala, Tista lower (plainland), lower chel, lower portion of Dharla, Lish Gish and the upper chel. The Tista lineament (TL) is extended along the Tista river where the Gish fault (GF) is present along the Gish river in the alluvial fill surface (Dasgupta et al. 2000, 2013; Mukul et al. 2014).

\subsubsection{Geomorphology}

The geomorphology database has been prepared using the Landsat 8-OLI satellite image and ASTER DEM data and updated with limited field observation for a better understanding of the landforms and their significance on active tectonics (figure 4c). By the digital processing of the satellite image, namely, histogram equalisation, band combinations, principal component analysis (PCA) techniques, followed by image interpretation, different landforms have been identified which vary from mountain terrain to peneplain surface. The anomalous geomorphic landforms which are associated with the different morphotectonic features can originate from active tectonic deformations (Howard 1967; Deffontaines and Chorowicz 1991) and are efficient indicators of recent seismotectonic activity (Nakata 1972; Deffontaines and Chorowicz 1991; Ferry et al. 2007).
The geomorphic landforms in the northern part of the study area originated by glacial and periglacial action, whereas in the southern part of the study area, landforms developed by fluvial action which have been greatly influenced by active tectonics. The glacial moraines and permafrost are predominant in the Rel chhu and Rathong chhu micro basin region in the north-western part. Also, glacial trough, arete and glacial lakes are also observed around Phedang in the north-eastern and Upper Rangpo chhu micro basin around the Nathang region. The central part of the study area is highly dissected by fluvial action and developed elongated numerous structural ridges, dissected structural mountains and narrow fluvial valleys. The landforms originate by the erosional action of the Tista river and its tributaries and have greater influence on the structural features. Along the mountain foothills, triangular facets with dissected mountains have been recognised which have a great impact on the mountain frontal thrust movement. In the southern part of the study region, mainly the Gish, Lish, Chel, Dharala and the Tista lower micro basin region is occupied by younger and older flood plains. Also, alluvial terraces which have a significant influence on active tectonics have been recognised in the quaternary geological surface.

\subsection{Computation of geomorphometric parameters}

Different geomorphotectonic parameters have been analysed, namely, linear, geometry of basin shape, areal and relief parameters as listed in table 3.

\subsubsection{Linear parameters}

The different linear parameters such as bifurcation ratio (BR), stream length ratio (SLR), stream sinuosity indices (SSI), fractural dimension of drainage network (FDDN) and hierarchical anomaly index (HAI) have been measured. Bifurcation ratio has been analysed to identify the relationship of the geological structure and tectonic activity with the branching pattern of the drainage network (Singh 2005; Asthana et al. 2015). Similarly, the stream length ratio has been analysed to determine the relative permeability of rock formation in the context of tectonic geomorphology (Shukla et al. 2014). The geometric structure of the drainage network can be altered by the influence of sub-surface geological structures which can be identified by stream sinuosity indices (Litchfield et al. 2003; Singh 2005). The fractal dimension of drainage 


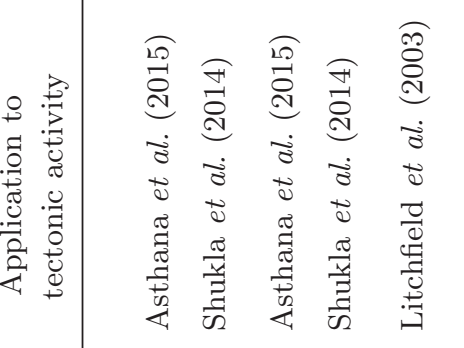

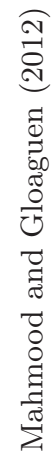

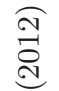

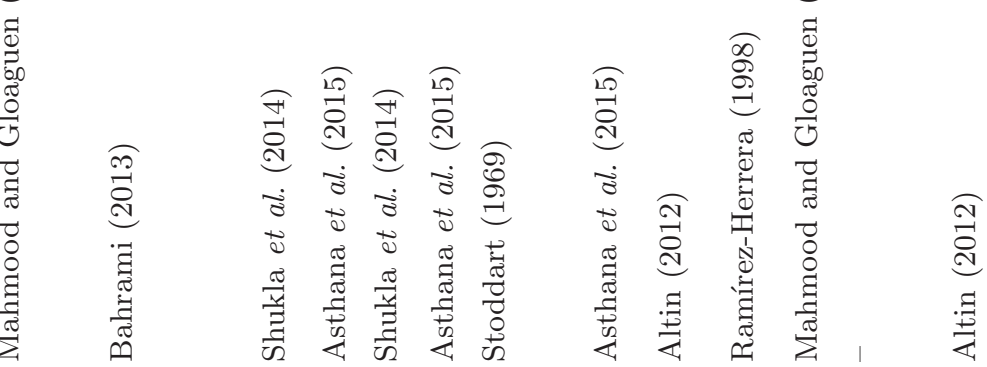

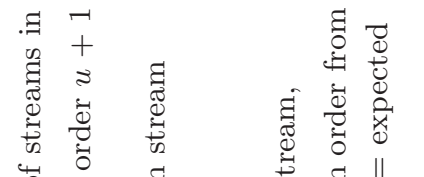

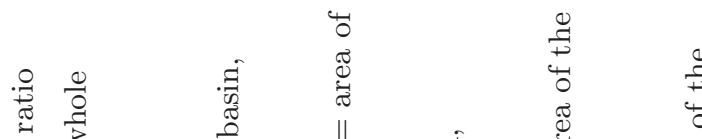

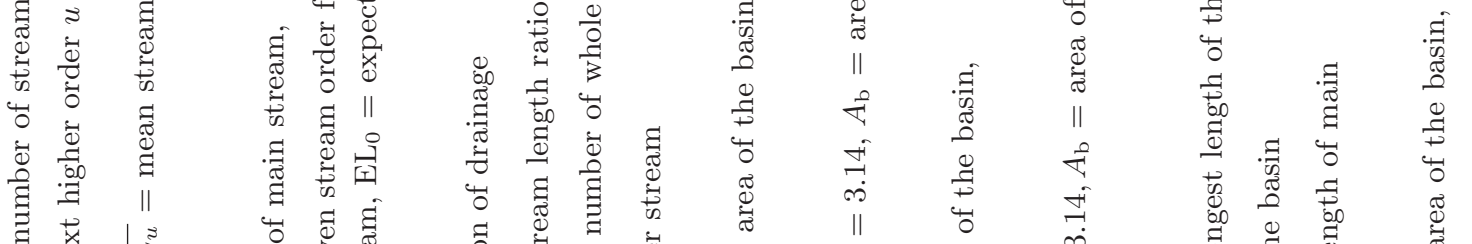

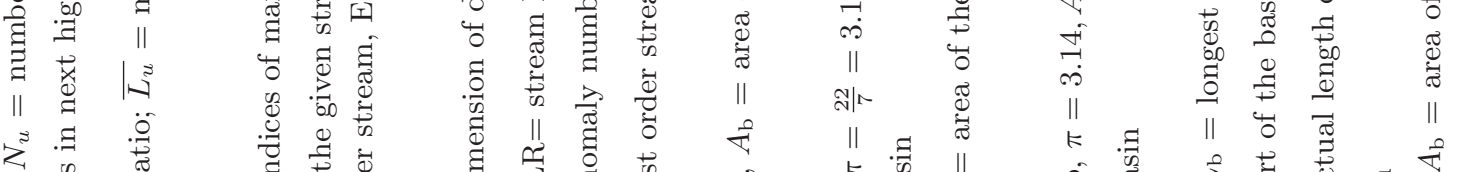

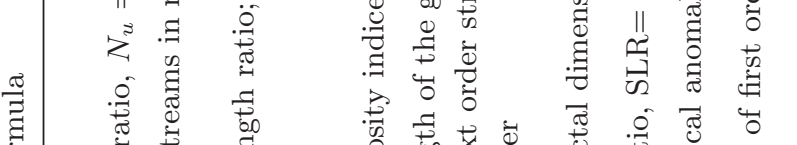

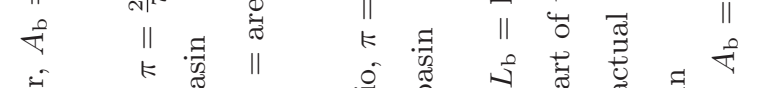

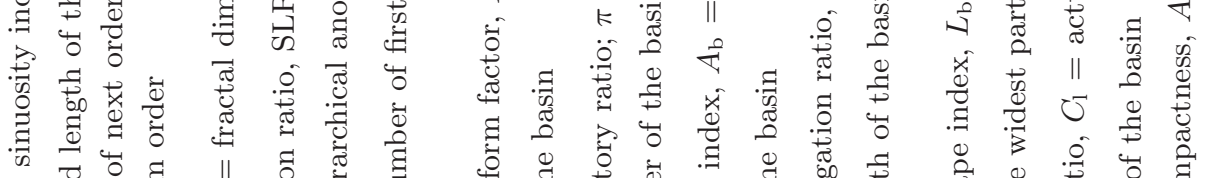

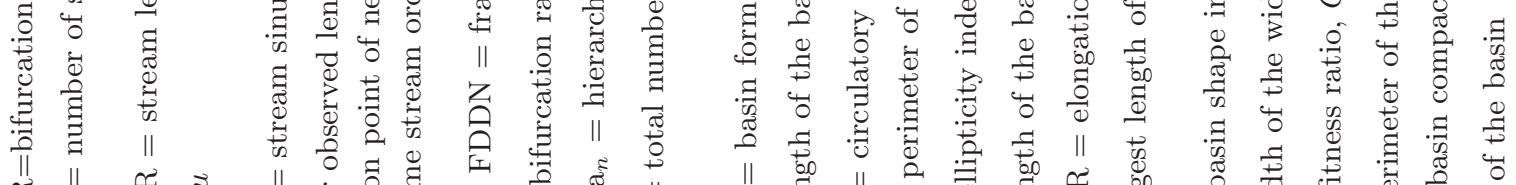

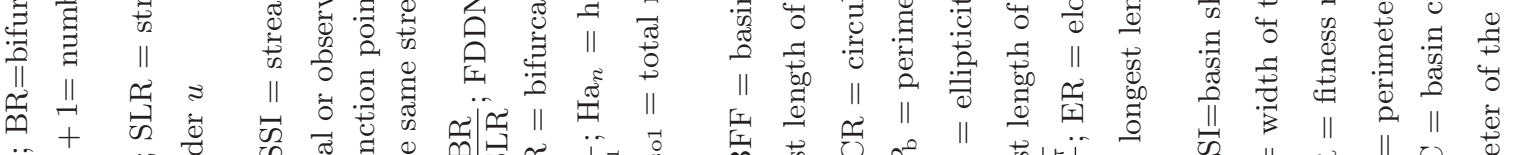

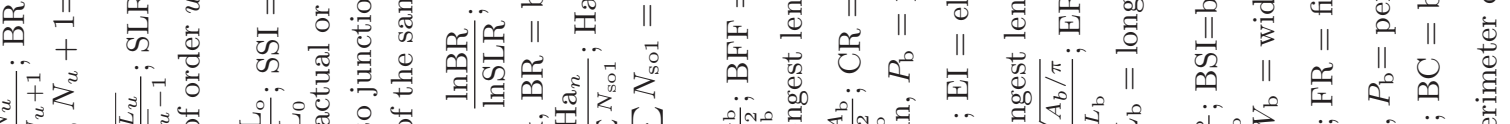
|

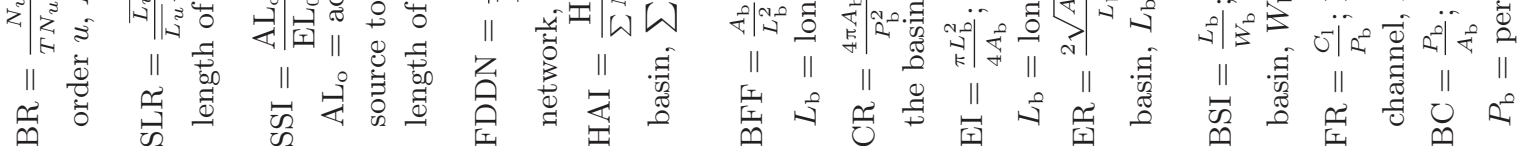

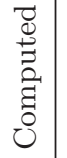

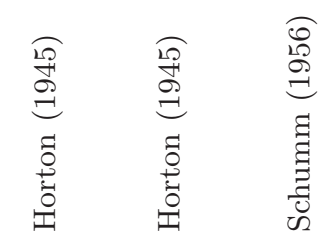

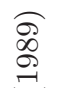

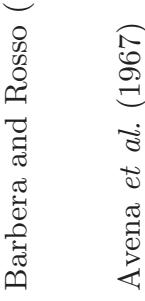

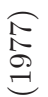

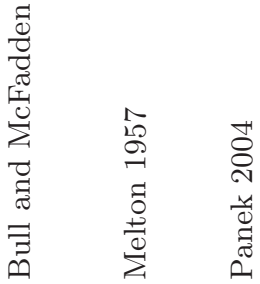

$\frac{2}{\frac{2}{6}}$

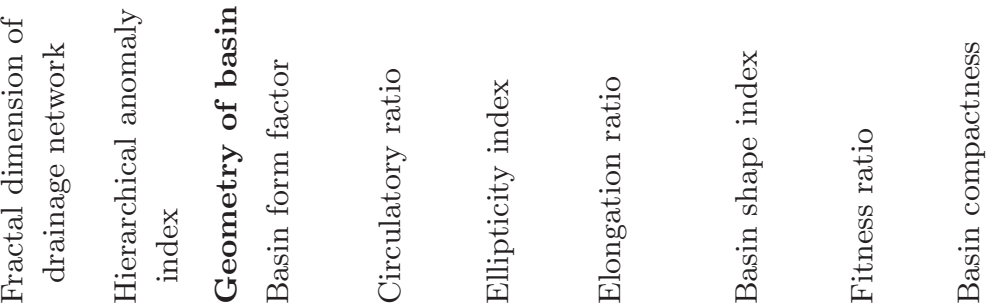




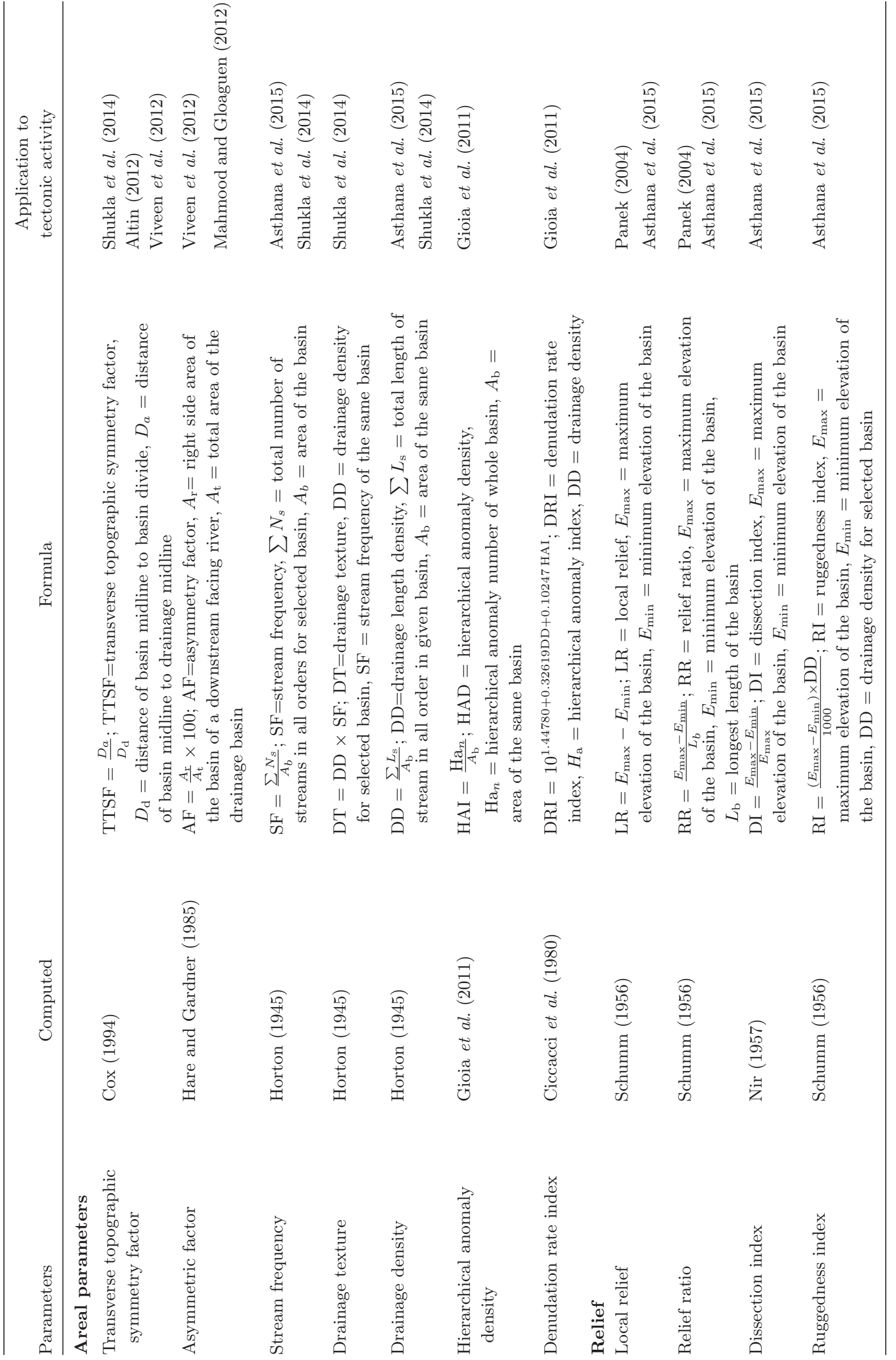


network estimates the degree of irregularities in the drainage network which helps to determine the neotectonic deformation in a region (Dombradi et al. 2007; Mahmood and Gloaguen 2012) and the perfectness of the drainage network and stream segmentation. Anomalies in stream order occur while the river course breaks the hierarchical order due to the lithological alteration and structural disturbance and produces an anomalous stream junction which is an indicator of tectonic activity and has been analysed by measuring the HAI (Bahrami 2013).

\subsubsection{Geometry of the river basin}

The geometry of the river basin defines various forms or shapes of the drainage basin which have a relation with its origin. The shape of the basin depends on the length of the main stream, basin perimeter and area which is controlled by relief, slope, geological structures and lithological characteristics of a particular region (Singh 2005). The different basin shapes are circular, elliptical and elongated which help in identifying the degree of tectonic influence. The various geometric parameters have been analysed, namely, circularity ratio (CR), elongation ratio (ER), ellipticity index (EI), basin form factor (BFF), basin shape index (BSI), basin compactness (BC), fitness ratio (FR), etc. which have a great significance with regard to the tectonic geomorphology (Ramírez-Herrera 1998; Shukla et al. 2014; Asthana et al. 2015). The various dependent parameters of geometric shapes such as basin area and perimeter, the longest and the widest length of the basin and the actual length of the main channel for basins have been measured from DEM (Cartosat DEM) in the GIS platform for understanding the significance of the geometric shape on active tectonics.

\subsubsection{Areal parameters}

Areal parameters measured the symmetricasymmetric nature as well as the intensity of topographic dissection for a particular drainage basin. The asymmetric nature estimated by measuring the asymmetric factor and the average transverse topographic symmetry (ATTS) factor while the estimation of drainage density (DD), frequency, texture, hierarchical anomaly density (HAD) and denudational rate have been measured for identifying the intensity of landscape dissection, structural and lithological control of a drainage 
network and its tectonic influence (Mahmood and Gloaguen 2012; Bahrami 2013; Shukla et al. 2014; Kaliraj et al. 2015). To estimate the symmetry factor, the various points have been selected along the main stream of each micro basin. The respective distance has been calculated for each point by drawing a line feature and the estimated values are used to compute the symmetry factor for each point. Similarly, to measure the asymmetric factor, the left and right side areas have been demarcated by the separation of the main stream of each micro basin (Keller and Pinter 2002; Mahmood and Gloaguen 2012). To estimate DD and stream frequency $(\mathrm{SF})$, the total number of streams and stream length has been computed after merging all stream order in one feature class database for the respective drainage micro basin and was extracted from the stream attribute table while the area of the same basin has been measured from the vector feature class in GIS. Drainage textures (DTs) have been computed based on SF and density (Singh 2005; Shukla et al. 2014). Furthermore, HAD and denudational rates index have been estimated to measure the degree of perfectness of the drainage hierarchical order and the degree of drainage segmentation and to identify the erosion rate with relation to the tectonic activity in the basin area (Bahrami 2013; Kaliraj et al. 2015).

\subsubsection{Relief parameters}

Different relief parameters, namely, local relief $(\mathrm{LR})$, relief ratio $(\mathrm{RR})$, dissection index (DI), ruggedness index (RI), stream length gradient index (SLGI), valley-floor width-height ratio (VFWHR), landscape roughness index (LRI) and hypsometric integral have been analysed. The LR and relief ratio have been measured for determining the morphological character of a terrain, the degree of dissections, the intensity of the erosion process which has greater significance to tectonic geomorphology (Panek 2004; Asthana et al. 2015). To estimate the relief parameters, the elevation value has been extracted from ASTER DEM and compared with the topographical map and field-based GPS observation data. Similarly, the DI and ruggedness index have been analysed for estimating the magnitude of dissection of a terrain and the degree of undulating topography which is highly influenced by the geological structural and tectonic geomorphological features (Singh 2005; Asthana et al. 2015). The stream length gradient index quantifies the deviation of a river along longitudinal profiles from its stable condition due to changes in slope which have a great connection with lithological resistance and neotectonic activity (Keller and Pinter 2002; Perez-Pena et al. 2010). To measure the stream length gradient index, the contour has been generated from ASTER DEM and used to compute the elevation difference surrounding the selected point. The hypsometric integral has been measured for studying the landscape dynamics which has a great impact on tectonic geomorphology (Keller and Pinter 2002). Similarly, landscape roughness has been estimated for measuring the vertical sinuosity of the landform on the basis of surface elevation change (Hassen et al. 2014) which depends on the variety of morphotectonic features at various scales (Panek 2004). The uplift and incision in the particular river basin have been measured by analysing the valley-floor width-height ratio which is influenced by the active tectonic movement (Keller and Pinter 2002; Viveen et al. 2012). To measure the valley-floor widthheight ratio, the river cross section has been drawn for each and every selected point in such a way that it can connect both sides of the nearest divider. The ASTER DEM has been used to prepare the cross profile along the selected cross section which measures the right and left sides of the divider height along with the valley floor height and width for a particular point.

\section{Results and discussion}

\subsection{Drainage morphometric analyses for the identification of geomorphometric anomalies}

The quantification of different morphometric parameters such as linear, areal and relief has been derived for all micro basins and suitable diagrams have been prepared for a comparative analysis of the parameters. The results of the morphometric analysis and its significance to tectono-geomorphometric evolution have been discussed below:

\subsubsection{Linear parameters}

A comparative study of the average stream length ratio (ASLR), average bifurcation ratio (ABR), average fractal dimension of drainage network (AFDDN), HAI and the average stream sinuosity indices (ASSI) shows some significant geomorphometric anomaly with reference to tectonic activity in the study area (figure 5 and table 4 ). The 
upper Rangpo chhu (MB 13) and Tista middle (MB 22) micro basins show a higher peak of ASLR (1.843 and 2.339, respectively), ABR (3.088 and 3.250 , respectively) and a lower value $(-1.337$ and 0.122 , respectively) with significant trough points of AFDDN, implying a tectonically deformed surface with geo-structural control on drainage development. Also, a higher peak of ASLR (3.750) and troughs of AFDDN (0.821) curve are recognised in the Lish micro basin (MB 07), indicating young geomorphic landforms with a high rate of neotectonic deformation where the geometry of the drainage network has been modified from a complex dendritic pattern to a linear stream in the zone of a topographic break due to the presence of an active thrust (Mahmood and Gloaguen 2012). Similarly, the Great Rangit micro basin (MB 17) shows a high peak of ABR (3.724) and a low AFDDN (-1.779) value with an anomalous trough point in the curve signifying the drainages are greatly controlled by the tectonic thrust movement and the regions are neotectonically deformed which represents significant geomorphic anomaly in this micro basin. Furthermore, it is observed that the Great Rangit micro basin (MB 17) and the Tista lower (foothills) micro basin (MB 23) represent higher values of HAI (2.801 and 6.097, respectively) and area of special scientific interest (ASSI) (1.644 and 1.523, respectively) with significant peak in the curve, indicating the presence of a compressed meander in the uplifted surface and the drainage hierarchical order has been crushed due to the higher strain of active thrust. Similarly, the Lish micro basin (MB 07) and Tista lower (plainland) micro basin (MB 24) have a lower value of ASSI (1.111) with the trough zone, indicating the presence of a lineament or fracture in the sub-surface along the river course. Lower Rangpo chhu micro basins (MB 14) show a higher peak of HAI (4.420) and a moderate value of ASSI (1.149), indicating the significant geomorphic anomaly of this micro basin. The compressed meanders in the Lesser Himalayan sequences along the Tista river and the linear valley between the MFT and the $\mathrm{MBT}$ are shown in figure $6(\mathrm{a}$ and $\mathrm{b})$.

\subsubsection{Geometry of the basin shape}

BFF, CR and ER show significant troughs while the EI and the BSI represent higher peaks in Karala (MB 01), Tista lower (plainland) (MB 24), Lish (MB 07), Dharla (MB 05), Upper chel (MB 04), Lower chel (MB 03) and the Tista lower foothills
(MB 23) micro basin region (figure 7 and table 4). The lower BFF, CR and ER values with the trough zone imply a more elongated basin which has been highly influenced by the structural disturbance and tectonic activity, indicating a higher geomorphometric anomaly (Zuchiewicz 1989; Altin 2012; Bali et al. 2012; Shukla et al. 2014). Similarly, the higher EI and BSI indexes produce a more elliptical and elongated basin due to compression and the uplifted mountain front which indicates high tectonic activity (Ramírez-Herrera 1998; Mahmood and Gloaguen 2012). Furthermore, it is recognised that the Rathong chhu (MB 16), Tista upper (MB 21), Ramman khola (MB 19) and the Rel chhu (MB 10) micro basin (0.222, 0.374, 0.266 and 0.266) shows a lower value of $\mathrm{BC}$ and significant trough zone in the curve, while the FR represents the peak value in Rill (MB 02), Gish (MB 06), Little rangit (MB 18) and the Dharala (MB 05) micro basin $(0.495,0.495,0.467$ and 0.441 , respectively) where tectonic compression and geomorphic anomaly are significant. The lower value of $\mathrm{BC}$ indicates high tectonic activity due to the presence of high resistance rocks influencing less segmentation of the basin ground plan (Panek 2004). Similarly, the higher FR value implies the anomaly in drainage adjustment due to tectonic activity where the long length of drainage has been adjusted in a narrow micro basin where geomorphometric anomalies are recognisable. The Karala (MB 01) and the Lish micro basin (MB 07) show a higher value with significant peak of BC (0.722 and 0.845, respectively) and the Lower chel (MB 04), Dik chhu (MB 03), Rayeng (MB 09) and Kalet Khola micro basin (MB 20) represent a lower value of FR (0.184, $0.312,0.336$ and 0.345 , respectively) in association with the trough zone. The higher $\mathrm{BC}$ value indicates a less resistant rocky surface which has been considered as an inactive zone (Panek 2004; Altin 2012) while the lower FR value signifies the almost perfect adjustment of drainage network in a micro basin which indicates low geomorphic anomaly.

The geometry of basin shape analysis shows that the widths of the Tista lower (foothills), Lish, Gish, Upper chel and Dharla micro basins are narrower near the mountain front along the MFT while they are much wider in the alluvial surface and more elongated in nature, indicating significant geomorphic anomaly in the micro basin (figure 8a and b). Also, the higher value of the FR in the Rill, Gish, Upper Chel and Lower Tista (foothills) micro basin indicates the anomaly in drainage adjustment and significant geomorphic anomaly. The continuous 


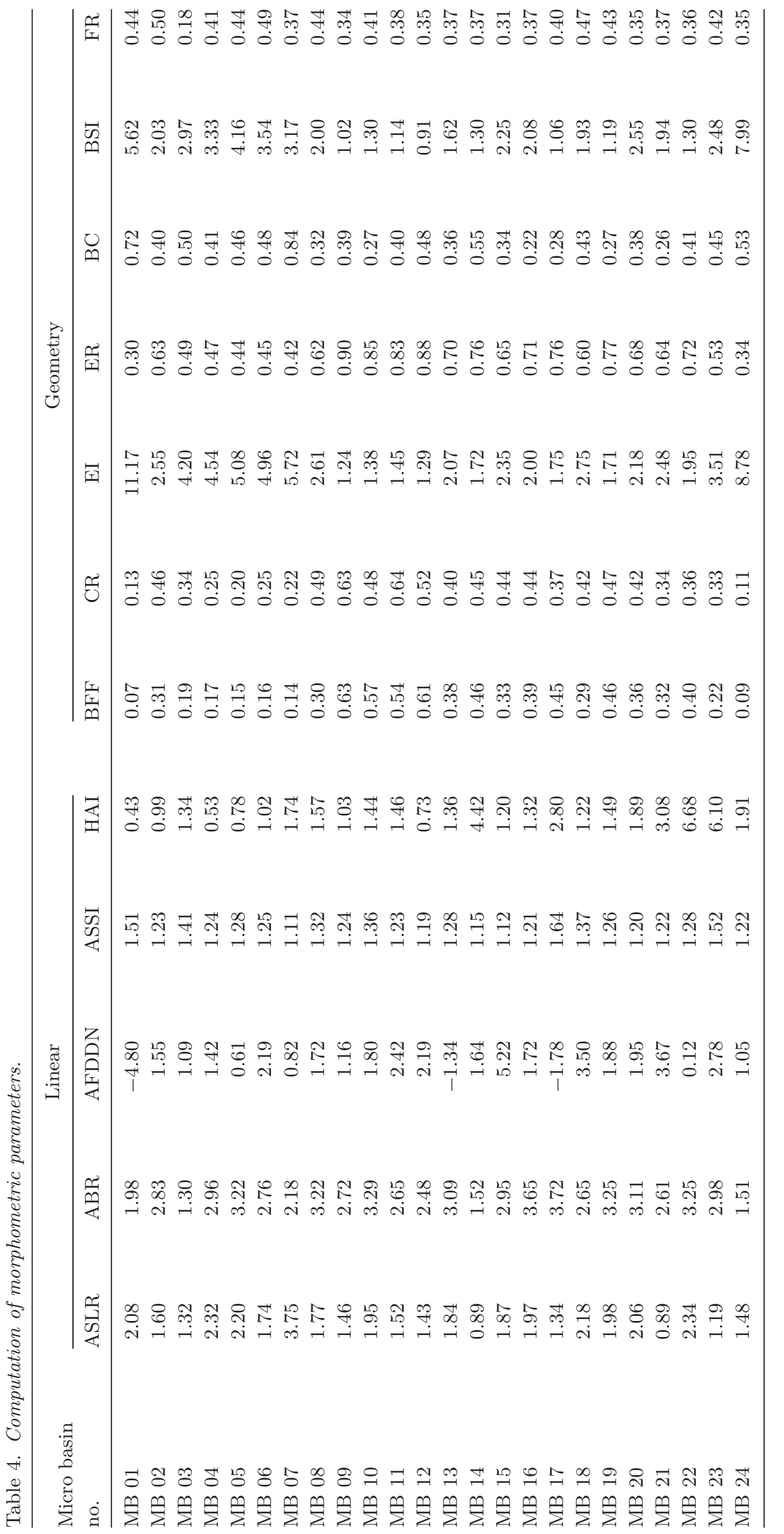




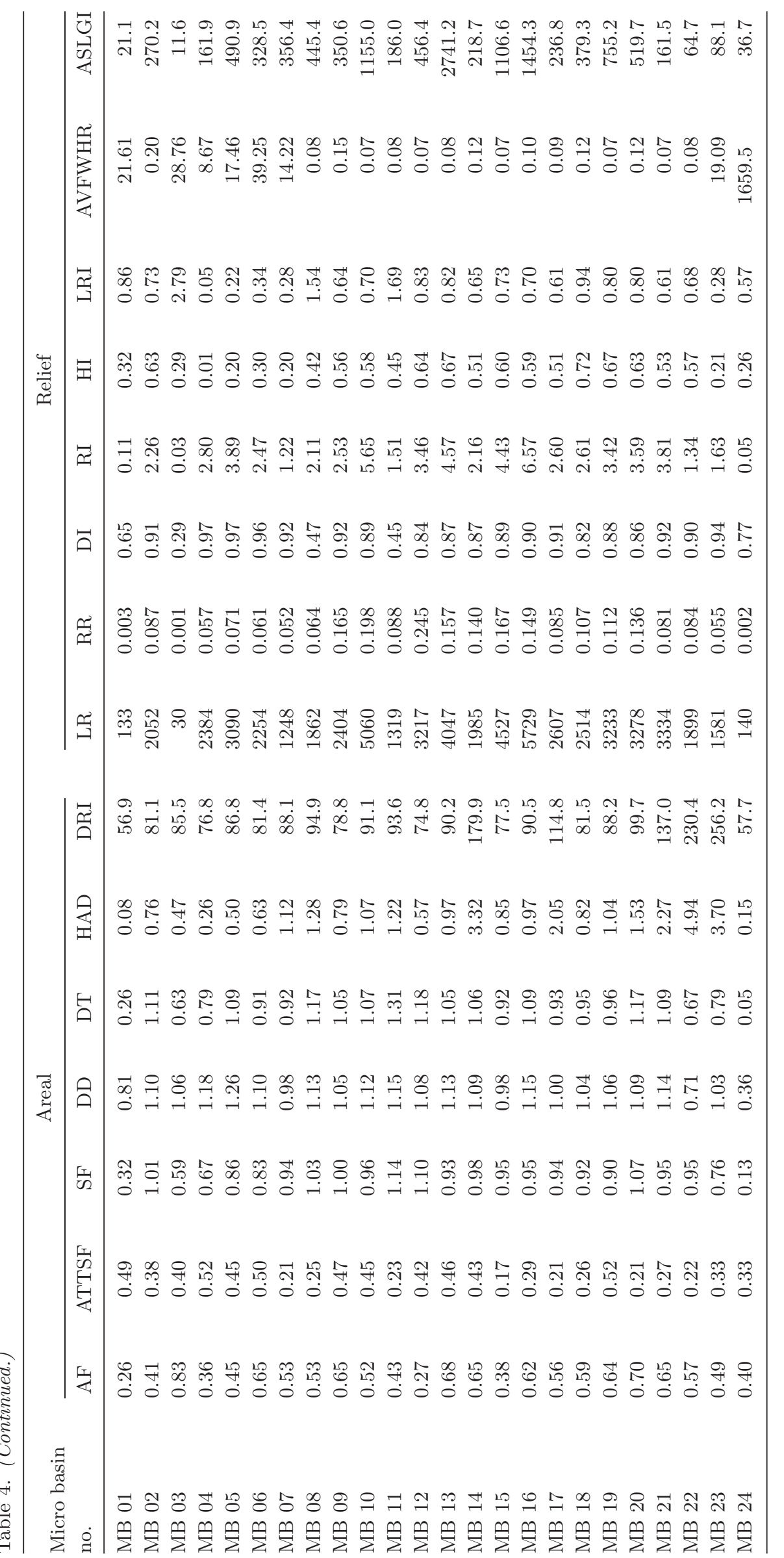




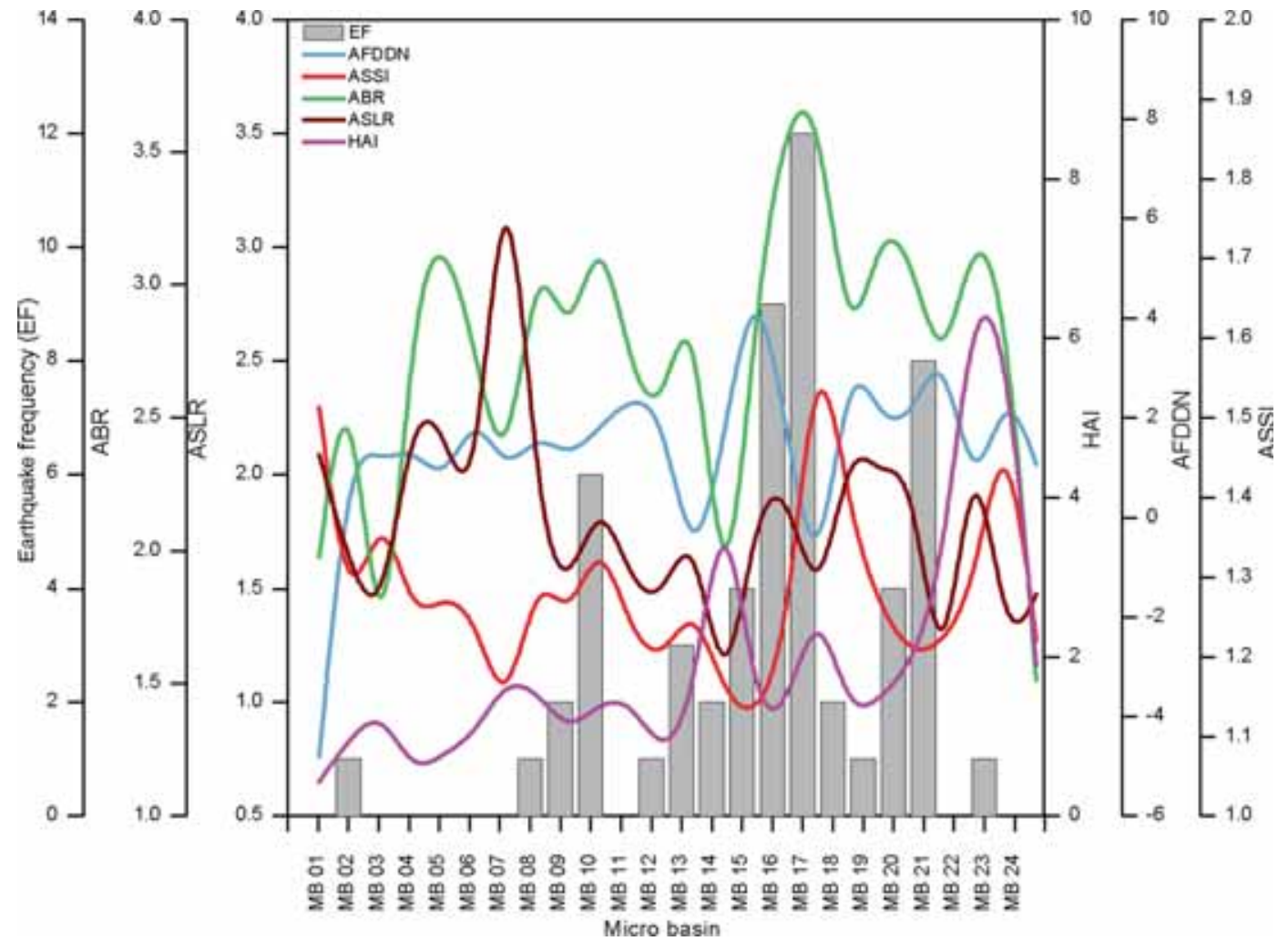

Figure 5. Linear parameters - average stream length ratio (ASLR), average bifurcation ratio (ABR), average fractal dimension of drainage network (AFDDN), hierarchical anomaly index (HAI) and average stream sinuosity indices (ASSI).
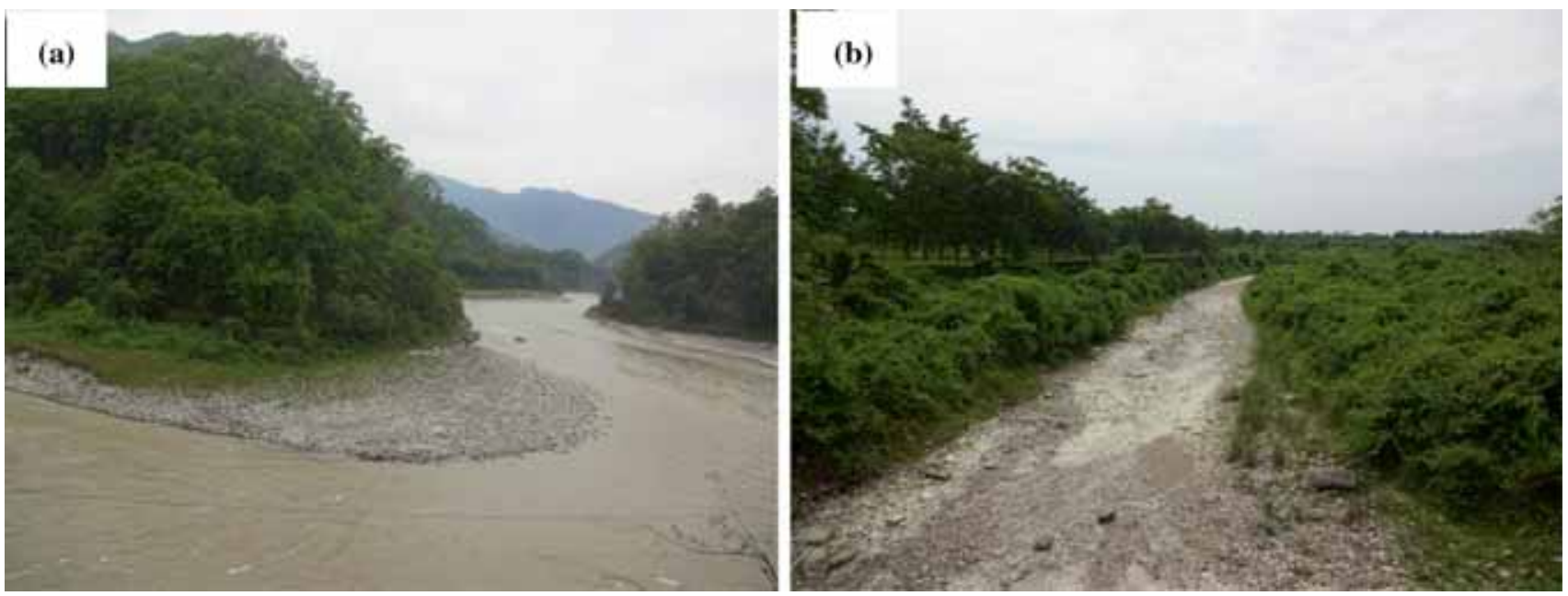

Figure 6. (a) Compressed meander in Lesser Himalayan sequences and (b) linear valley in between MFT and MBT.

evolution of drainage in the Rayeng and Resi micro basins is due to active tectonic compression of MFT and MBT, resulting in the conversion of the elongated shape to a more circular shape of micro basin, indicating the anomalous geomorphometric nature of the basin shape.

\subsubsection{Analysis of areal parameters}

The geomorphometric graph of areal parameters (figure 9 and table 4) shows that the Kalet khola micro basin (MB 20) has a higher peak of asymmetry factor $(\mathrm{AF})$ and the troughs of the ATTSF 

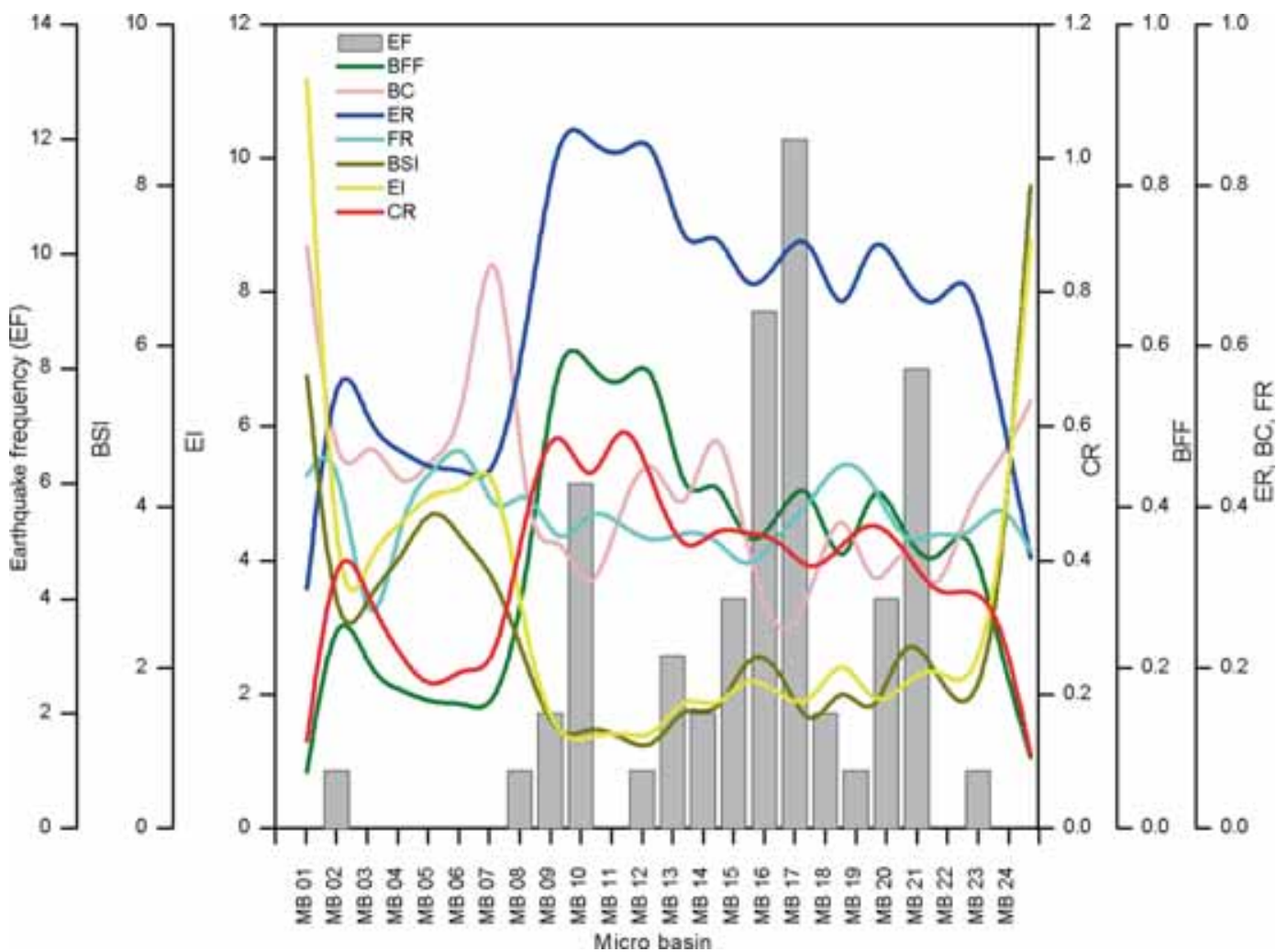

Figure 7. Geometric form of the basin - basin form factor (BFF), circulatory ratio (CR), elongation ratio (ER), basin compactness (BC), fitness ratio (FR), ellipticity index (EI) and basin shape index (BSI).
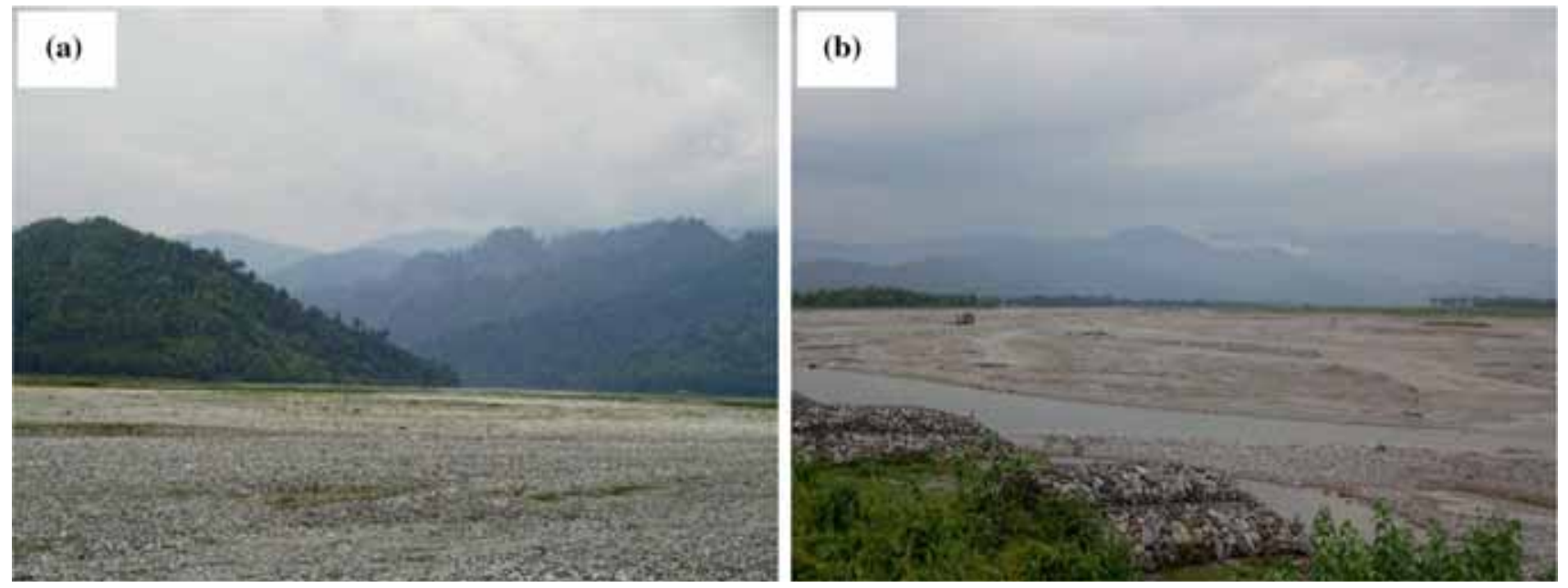

Figure 8. (a) Uplifted mountain front along MFT near to Lish river basin - changes of the river basin shape from linear to elongated and (b) elongated basin of the Chel river at the alluvial surface after the frontal thrust.

curve indicate a tectonic tilt in the left side with less drainage migration. Karala micro basin (MB 01) shows troughs of AF and peaks of the ATTSF curve, indicating a tectonic tilt on the right side of the micro basin with significant drainage migration. Ramman khola (MB 19) and the lower and upper Rangpo chhu micro basins (MB 13 and
MB 14) show a higher peak of AF and ATTSF, indicating a surface tilt on the left side with a high magnitude of stream migration. Dik chhu (MB 15), Rani khola (MB 08) and Lish micro basin (MB 07) are tectonically stable and the geomorphic anomaly is less as it shows the symmetric curves of ATTSF (very close to 0 ) and $A F$ (very close to 0.5 ). The 


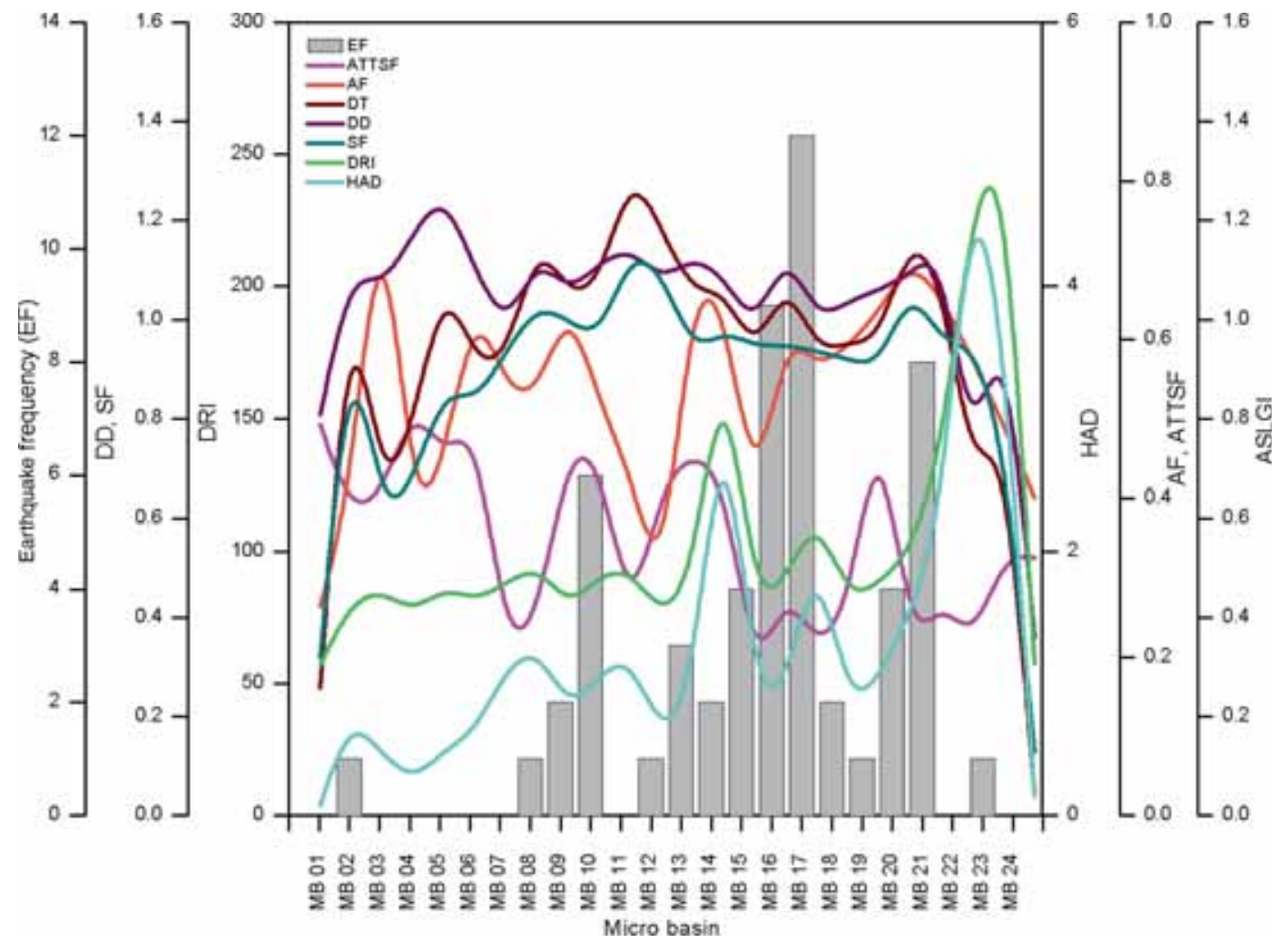

Figure 9. Areal parameters - asymmetry factor (AF), average transverse topographic symmetry factor (ATTSF), stream frequency $(\mathrm{SF})$, drainage density (DD), drainage texture (DT), hierarchical anomaly density (HAD) and denudation rate index (DRI).
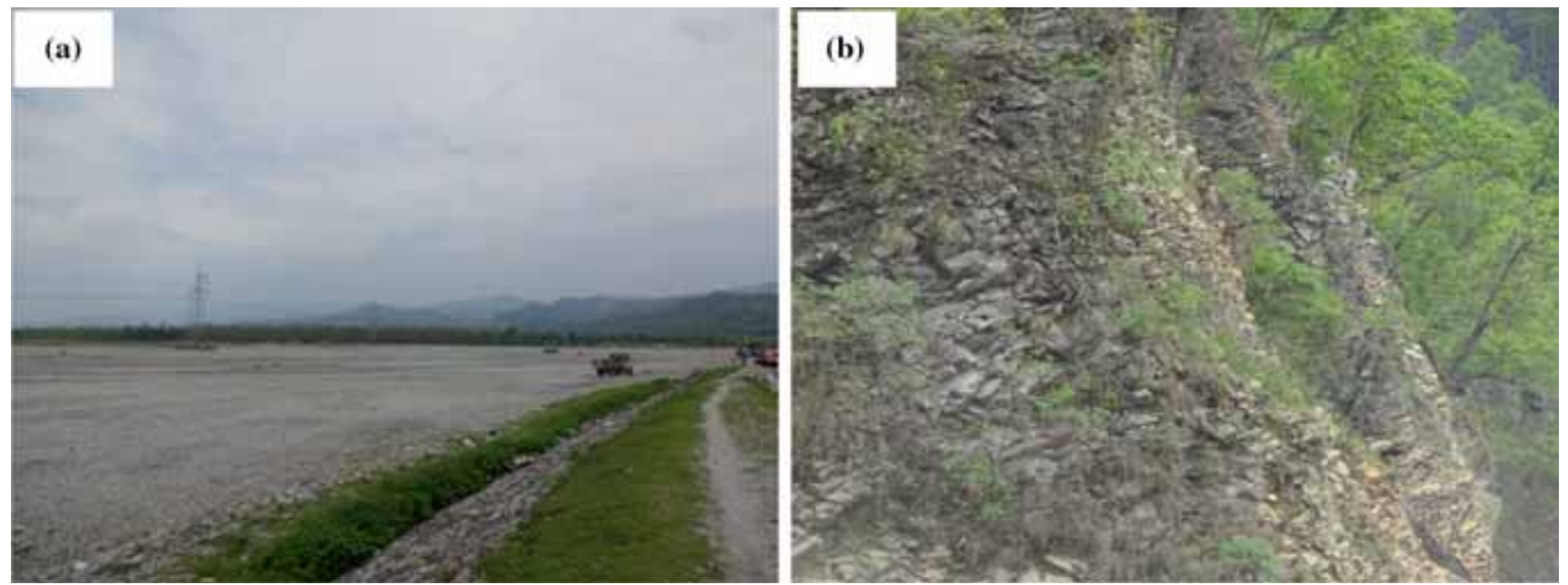

Figure 10. (a) Tectonic tilt of the Gish river in the alluvial surface and (b) high rate of weathering and denudation process in the Lesser Himalayan sequence.

tectonic tilt is also observed in Gish (MB 06) and the Upper Chel river basin (MB 04) and it has also been witnessed in the field (figure 10a).

A comparison of the SF, DD and DT curves shows (figure 9 and table 4 ) that the Rill (MB 02), Dharla (MB 05), Rani khola (MB 08), Kalet (MB 20) and Tista upper micro basin (MB 21) represents a higher peak of SF, DD and DT, indicating significant geomorphic anomaly of the micro basin, while the Lower chel (MB 03) and Dik chhu (MB 15) show a relatively lower trough of the SF, DD and DT curves, indicating less geomorphic anomaly. The Rathong chhu micro basin (MB 16) represents a higher peak of DD and DT 


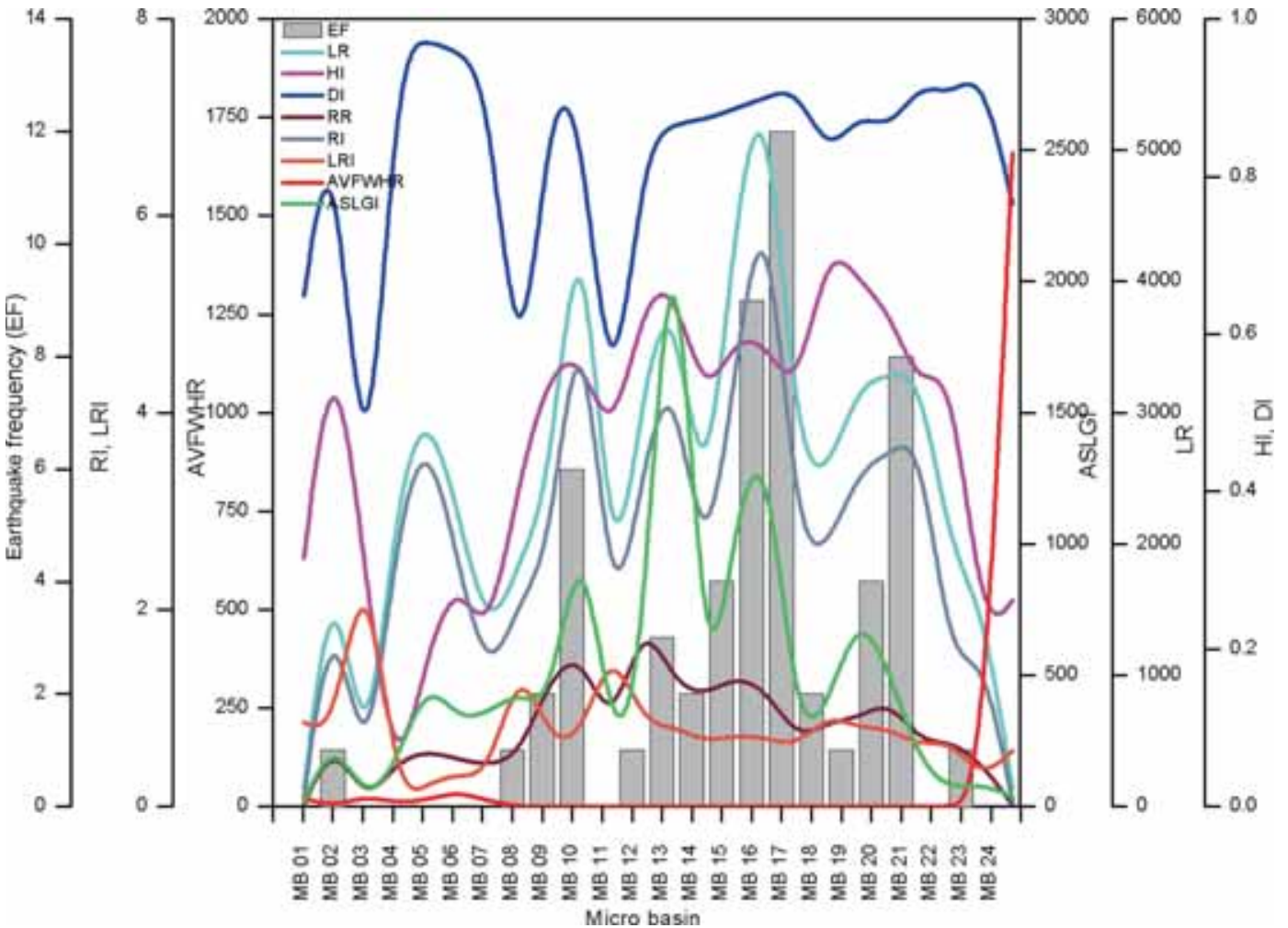

Figure 11. Relief parameters - local relief (LR), dissection index (DI), ruggedness index (RI), relief ratio (RR), average stream length gradient index (ASLGI), hypsometric integral (HI), average valley-floor width-height ratio (AVFWHR) and landscape roughness (LRI).
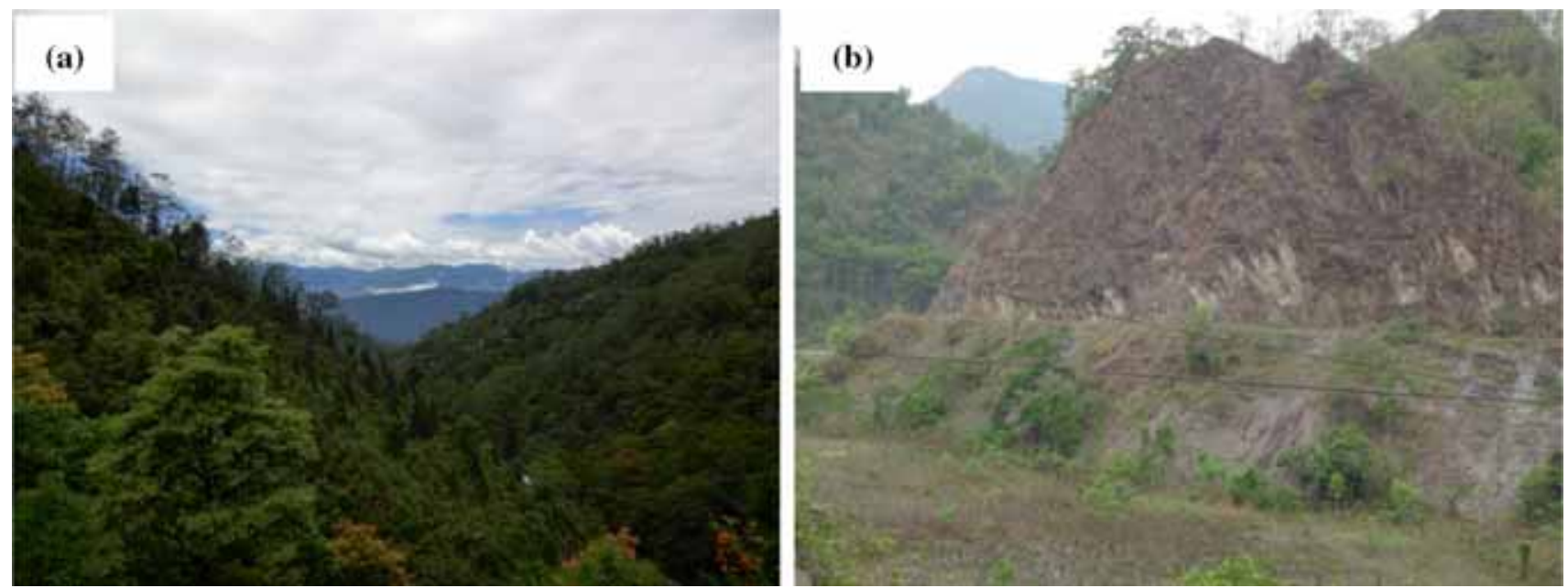

Figure 12. (a) V-shaped narrow valley and (b) relief steepness and high resistance surface in the Lesser Himalayan sequence.

while a higher peak of the SF and DT curve is observed in the Rangli micro basin (MB 12), indicating the presence of a high-resistance lithological surface where an undulating topography has been generated due to the MBT and MCT active thrust movement. Similarly, the Tista middle (MB 22) and the Tista (plainland) (MB 24) show a trough zone of the DD and DT curves, indicating less resistance surface and have been less influenced by tectonic activity.

Tista middle (MB 22), Tista foothills (MB 23), Lower Rangpo chhu (MB 14), Tista upper (MB 21 ) and Great rangit (MB 17) have a higher value of $\mathrm{HAD}(4.943,3.703,3.316,2.272$ and 2.047, respectively) and a denudation rate index (DRI) $(230.39,256.23,179.91,137.00$ and 114.79, 
Table 5. Correlation of morphometric parameters.

\begin{tabular}{|c|c|c|c|c|c|c|c|c|c|c|c|c|c|}
\hline & ASLR & ABR & FDDN & ASSI & HAI & $\mathrm{BFF}$ & $\mathrm{CR}$ & EI & ER & $\mathrm{BC}$ & BSI & FR & $\mathrm{AF}$ \\
\hline ASLR & 1.00 & & & & & & & & & & & & \\
\hline $\mathrm{ABR}$ & 0.18 & 1.00 & & & & & & & & & & & \\
\hline FDDN & -0.17 & 0.07 & 1.00 & & & & & & & & & & \\
\hline ASSI & -0.22 & 0.17 & -0.50 & 1.00 & & & & & & & & & \\
\hline HAI & -0.22 & 0.04 & 0.07 & 0.19 & 1.00 & & & & & & & & \\
\hline $\mathrm{BFF}$ & -0.32 & 0.35 & 0.21 & -0.13 & 0.08 & 1.00 & & & & & & & \\
\hline $\mathrm{CR}$ & -0.31 & 0.30 & 0.40 & -0.19 & -0.01 & 0.88 & 1.00 & & & & & & \\
\hline EI & 0.27 & -0.50 & -0.50 & 0.19 & -0.22 & -0.83 & -0.85 & 1.00 & & & & & \\
\hline ER & -0.32 & 0.40 & 0.28 & -0.14 & 0.13 & 0.99 & 0.90 & -0.89 & 1.00 & & & & \\
\hline $\mathrm{BC}$ & 0.42 & -0.68 & -0.36 & -0.08 & -0.04 & -0.53 & -0.53 & 0.68 & -0.59 & 1.00 & & & \\
\hline BSI & 0.17 & -0.47 & -0.29 & 0.03 & -0.21 & -0.81 & -0.83 & 0.92 & -0.86 & 0.50 & 1.00 & & \\
\hline FR & 0.16 & 0.41 & -0.09 & 0.16 & -0.11 & -0.15 & -0.11 & 0.11 & -0.14 & -0.05 & 0.03 & 1.00 & \\
\hline $\mathrm{AF}$ & -0.15 & 0.00 & 0.13 & 0.00 & 0.23 & 0.14 & 0.20 & -0.38 & 0.20 & -0.26 & -0.32 & -0.32 & 1.00 \\
\hline ATTSF & -0.14 & -0.17 & -0.30 & 0.06 & -0.35 & -0.04 & -0.14 & 0.21 & -0.09 & 0.08 & 0.14 & 0.21 & -0.05 \\
\hline $\mathrm{SF}$ & 0.01 & 0.53 & 0.41 & -0.29 & 0.08 & 0.70 & 0.77 & -0.86 & 0.76 & -0.42 & -0.88 & 0.11 & 0.24 \\
\hline DD & -0.05 & 0.40 & 0.26 & -0.08 & -0.27 & 0.30 & 0.45 & -0.53 & 0.35 & -0.34 & -0.60 & 0.18 & 0.24 \\
\hline DT & -0.07 & 0.50 & 0.43 & -0.30 & -0.11 & 0.62 & 0.73 & -0.80 & 0.68 & -0.45 & -0.79 & 0.16 & 0.22 \\
\hline HAD & -0.19 & 0.18 & 0.09 & 0.13 & 0.96 & 0.24 & 0.15 & -0.38 & 0.29 & -0.13 & -0.41 & -0.05 & 0.26 \\
\hline DRI & -0.24 & 0.13 & 0.12 & 0.21 & 0.96 & 0.11 & 0.06 & -0.29 & 0.16 & -0.08 & -0.31 & -0.03 & 0.22 \\
\hline LR & 0.03 & 0.69 & 0.35 & -0.25 & -0.14 & 0.49 & 0.39 & -0.60 & 0.54 & -0.67 & -0.49 & 0.10 & 0.12 \\
\hline $\mathrm{RR}$ & -0.11 & 0.39 & 0.33 & -0.34 & -0.10 & 0.81 & 0.68 & -0.72 & 0.82 & -0.44 & -0.67 & -0.06 & 0.00 \\
\hline DI & 0.19 & 0.44 & 0.12 & -0.19 & 0.18 & 0.07 & -0.15 & -0.15 & 0.09 & -0.12 & -0.10 & 0.41 & -0.09 \\
\hline RI & 0.02 & 0.67 & 0.33 & -0.25 & -0.20 & 0.45 & 0.36 & -0.56 & 0.50 & -0.66 & -0.45 & 0.13 & 0.12 \\
\hline $\mathrm{HI}$ & -0.21 & 0.31 & 0.19 & -0.13 & 0.01 & 0.69 & 0.66 & -0.63 & 0.72 & -0.51 & -0.61 & 0.00 & 0.25 \\
\hline LRI & -0.27 & -0.35 & 0.00 & 0.15 & -0.14 & 0.12 & 0.33 & -0.12 & 0.13 & -0.06 & -0.15 & -0.53 & 0.33 \\
\hline AVFWHR & -0.11 & -0.42 & -0.04 & -0.10 & -0.01 & -0.34 & -0.44 & 0.49 & -0.39 & 0.18 & 0.74 & -0.14 & -0.20 \\
\hline ASLGI & 0.14 & 0.41 & -0.02 & -0.19 & -0.24 & 0.27 & 0.23 & -0.33 & 0.30 & -0.38 & -0.27 & -0.02 & 0.19 \\
\hline
\end{tabular}

respectively) with a significant peak in the curve (figure 9 and table 4). The higher value of HAD is associated with the heterogeneous land surface with mass movements of weathered material, indicating high tectonic activity (Bishop 2007; Kaliraj et al. 2015) as shown in figure 10(b). Also, a significant higher peak has been observed in the Lower Rangpo chhu, Great rangit (MB 17) and Tista lower (foothills) micro basin (MB 23) in both HAD and DRI curves, indicating significant weathering on the heterogeneous surface. MCT, MFT and MBT have a greater impact of producing a heterogeneous lithological surface where weathering is also high. Karala (MB 01) and Tista lower (plainland) (MB 24) show a lower value of HAD (0.081 and 0.152 , respectively) and DRI is 56.88 and 57.68, respectively, indicating less drainage anomaly in a uniform lithology (figure 10a).

\subsubsection{Relief parameters}

The comparative geomorphometric curve has been prepared based on the relief parameters (figure 11).
The LR curve represents a significant peak in the Rel chhu (MB 10), Upper Rangpo chhu (MB 13), Rathong chhu (MB 16), Dharla (MB 05) and the Rill micro basin (MB 02) region where the highest and lowest elevation differences are more and the lower chel (MB 03), Resi (MB 11), lower Rangpo chhu (MB 14) and great rangit (MB 17) show a trough where the differences between the maximum and the minimum elevation is less. The higher LR is associated with the high and steep mountainous regions where asymmetric drainage distribution is observed and is strongly indicated by geomorphic anomaly. Similarly, the lower LR is observed in a plain flat surface where a gentle slope and least DD is observed while it is associated with low tectonic activity with less disturbance by geostructural features.

The Lower chel (MB 03), Resi (MB 11) and Rani khola micro basin (MB 08) show a lower value of the DI $(0.29,0.45$ and 0.47 , respectively) with significant trough and a higher value of the LRI $(2.79,1.69$ and 1.54) with a significant 
Table 5. (Continued.)

\begin{tabular}{rrrrrrrrrrrrrr}
\hline ATTSF & \multicolumn{1}{c}{ SF } & DD & DT & HAD & DRI & LR & RR & DI & RI & HI & LRI & AVFWHR & ASLGI \\
\hline-0.29 & 1.00 & & & & & & & & & & & & \\
0.19 & 0.67 & 1.00 & & & & & & & & & & & \\
-0.14 & 0.94 & 0.83 & 1.00 & & & & & & & & & & \\
-0.37 & 0.31 & -0.10 & 0.10 & 1.00 & & & & & & & & & \\
-0.25 & 0.19 & -0.05 & 0.04 & 0.95 & 1.00 & & & & & & & & \\
-0.04 & 0.55 & 0.48 & 0.58 & 0.00 & -0.06 & 1.00 & & & & & & & \\
0.02 & 0.67 & 0.38 & 0.64 & 0.05 & -0.04 & 0.77 & 1.00 & & & & & & \\
0.12 & 0.18 & 0.07 & 0.13 & 0.21 & 0.21 & 0.50 & 0.36 & 1.00 & & & & & \\
0.03 & 0.53 & 0.55 & 0.61 & -0.07 & -0.11 & 0.99 & 0.73 & 0.48 & 1.00 & & & & \\
-0.22 & 0.55 & 0.10 & 0.44 & 0.15 & -0.02 & 0.53 & 0.69 & 0.08 & 0.47 & 1.00 & & & \\
-0.13 & 0.02 & 0.06 & 0.03 & -0.14 & -0.16 & -0.30 & -0.15 & -0.92 & -0.30 & 0.18 & 1.00 & & \\
-0.04 & -0.69 & -0.78 & -0.66 & -0.21 & -0.20 & -0.36 & -0.35 & -0.07 & -0.35 & -0.24 & -0.08 & 1.00 & \\
0.10 & 0.28 & 0.29 & 0.33 & -0.17 & -0.20 & 0.71 & 0.54 & 0.20 & 0.71 & 0.44 & -0.07 & -0.17 & 1.00 \\
\hline
\end{tabular}

peak indicating highly dissected undulating strong erosional potential topography due to the influence of tectonic activity. The Resi micro basin is affected by the MBT and MFT thrusts while the Rani khola micro basin has greater control over MCT. Also, the Lower chel is greatly influenced by lineament and micro fractures in the alluvial surface where significant evidence of neotectonic activities is recognised. Similarly, the lower RI is observed in the Lower chel (MB 03), Tista plainland (MB 24) and Karala (MB 01) micro basin (0.03, 0.05 and 0.11 , respectively) while the Upper chel (MB 03), Dharla (MB 05), Tista lower foothills (MB 23) and Lish (MB 07) micro basin show a lower value of LRI $0.05,0.22,0.28$ and 0.28 , respectively, which are located in less resistant alluvial surface and less affected by structural features. It is also observed that the RI curve is very similar to the LR curve, indicating the topography of the region is greatly affected by fluvial erosion and DD and its anomalous nature which has been greatly controlled by tectonic activity.

The comparative study of the RR and HI graph shows that the Rel chhu (MB 10) and Rill (MB 02) micro basin have significant peaks in both $\mathrm{HI}$ and $\mathrm{RR}$ curves where the MCT and MBT influence is significant (figure 11). Resi (MB 11), Great rangit (MB 17), Tista lower (foothills) (MB 23) and Lower Rangpo chhu (MB 14) show a significant drop in the $\mathrm{HI}$ and RR curves, indicating that the transformation of the youthful stage to the mature stage in the drainage development cycle are very active. The Lower chel (MB 03) and the Tista lower plainland (MB 24) micro basin show a significant drop in the RR curve as the micro basin reaches the old stage of drainage development and represents a peneplain surface with the presence of less resistance rocks.

The significant lower value of average valley-floor height-width ratio (AVFHWR) has been observed in high elevated micro basins, whereas a significant higher value of average stream length gradient index (ASLGI) is recognised in the Dik (MB 15), Rel (MB 10), Rathong (MB 16) and Upper Rangpo chhu (MB 13) micro basin (2741.17, 1454.35, 1154.96 and 1106.64, respectively) (figure 11). The lower AVFWHR produces a 'v'-shaped narrow valley which is actively incised due to a high rate of uplift (Keller and Pinter 2002; Mahmood and Gloaguen 2012), while the higher ASLGI in the high-resistant narrow valley indicates high tectonic activity (Keller and Pinter 2002; Mahmood and Gloaguen 2012). The higher value of AVFHWR and lower value of ASLGI are recognised in the Tista lower (plainland) (MB 24), Lower chel (MB 03) and Karala (MB 01) micro basin which may be crushed by the active fault movement, indicating the presence of a strike-slip fault and produces a much wider valley (Keller and Pinter 2002; Mahmood and Gloaguen 2012). The v-shaped valley is shown in figure $12(\mathrm{a})$ and the high-resistance surface in the Lesser Himalayan sequence is presented in figure 12(b). A comparison between the AVFHWR and ASLGI curves (figure 11) shows that the Rel chhu (MB 10), Upper Rangpo (MB 13), Rathong (MB 16) and the Ramman khola (MB 19) micro basin have a significant peak and trough in the ASLGI and AVFHWR curves, respectively, which produces a steep-sided narrow valley in the resistance surface where the 


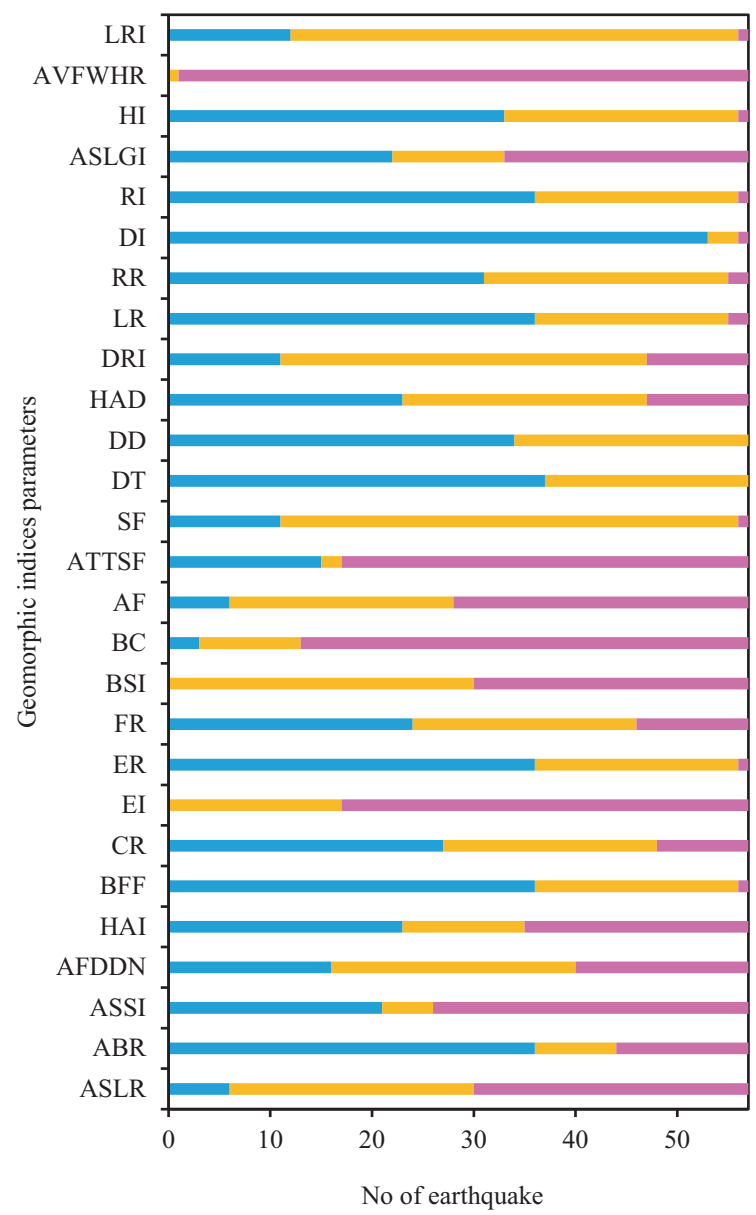

migh indexed value $\backsim$ Medium indexed value $₫$ Low indexed value
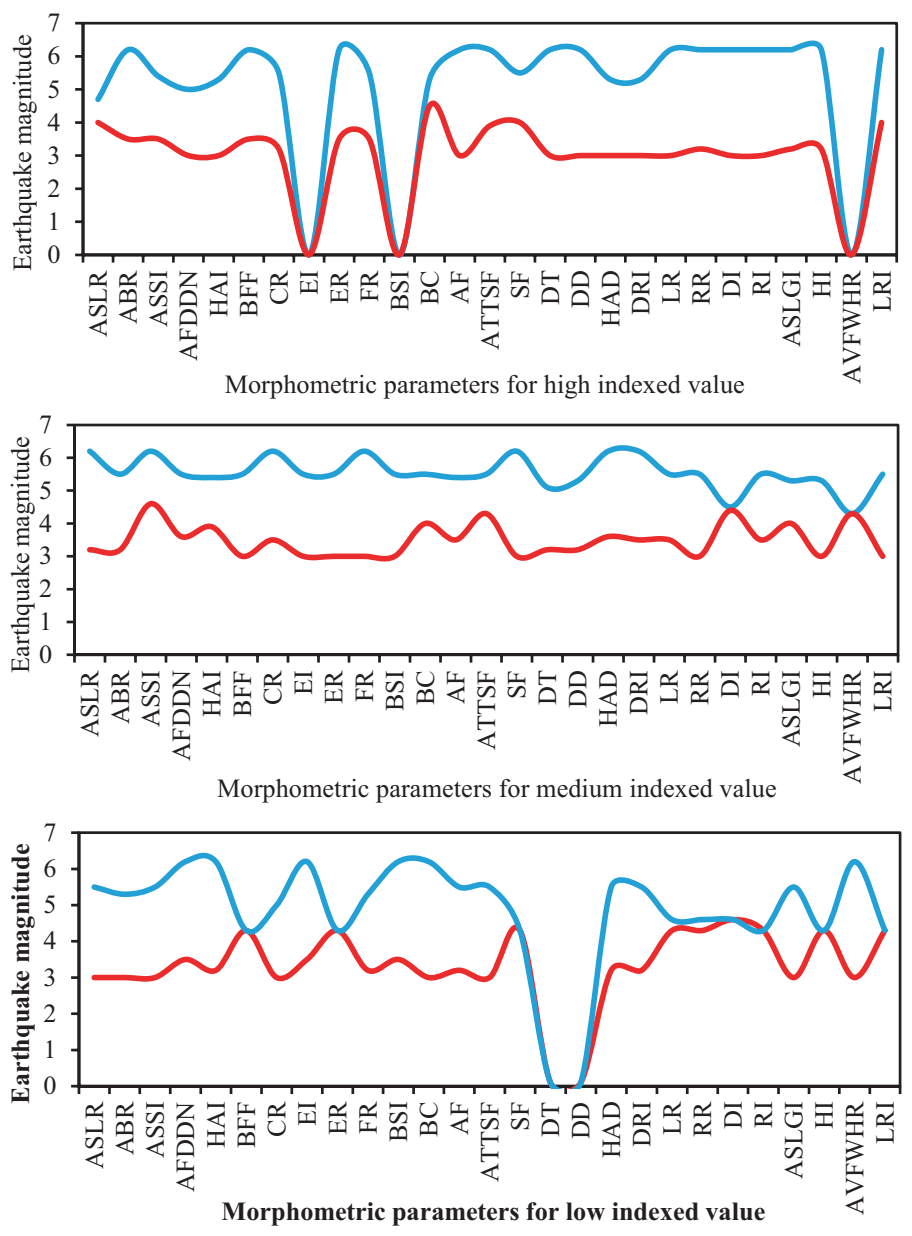

Low magnitude earthquake $\quad$ High magnitude earthquake

Figure 13. Relationship of morphometric parameters with earthquake frequency and magnitude.

tectonic influence of MCT and MBT are significant, indicating the high geomorphic anomaly of these micro basins.

The correlation analysis among the parameters has been carried out (table 5) and the interdependence of parameters has been identified with special reference to seismotectonic activity. The analysis shows that $\mathrm{ABR}$ is interdependent on $\mathrm{BC}$ $(-0.68)$ and RI (0.67), indicating that the evolution of the drainage network depends on the structural control and the resistance of rocks. Similarly, AFDDN have significant correlation with ASSI $(-0.50)$, which implies the relationship of the neotectonic deformation with the channel pattern. Also, it is observed that HAI has a good correlation with DRI (0.96), indicating that stream segmentation is strongly affected by the mass movement of weathered materials. The shape, specifically, CR and BSI have a good relation with SF (0.77), RR (-0.67) and AVFHWR (0.74), respectively, by the structural and lithological unit and the continuous upliftment causes the change in the shape of the basin. DRI has a very good relation with HAD (0.95), indicating that the drainage hierarchical order and degree of drainage segmentation depends on the tectonic movement and structural features. The correlation also shows that ASLGI has a good relation with RR (0.54), RI (0.71) and HI (0.44), respectively, which suggests the relationship of rock resistance with the degree of dissection, landscape dynamics and tectonic activity. DI has a very good relation with LRI $(-0.92)$ and also with BSI, indicating that the evolution of the basin shape modifies the drainage pattern and the dynamic changes of landform.

\subsection{Significance of geomorphometric anomalies on seismotectonic activity}

The morphometric parameters have been integrated with seismological databases to study their role in seismotectonic activity. The computed 
Table 6. Relationship between morphometric parameters and past seismic activity.

\begin{tabular}{|c|c|c|c|c|c|}
\hline $\begin{array}{l}\text { Sl. } \\
\text { no. }\end{array}$ & Parameters & Range & $\begin{array}{l}\text { No. of } \\
\text { earthquakes }\end{array}$ & $\begin{array}{l}\text { Highest } \\
\text { magnitude }\end{array}$ & $\begin{array}{l}\text { Lowest } \\
\text { magnitude }\end{array}$ \\
\hline \multirow[t]{3}{*}{1} & \multirow[t]{3}{*}{ Avg. stream length ratio (ASLR) } & $>1.98$ & 6 & 4.7 & 4.0 \\
\hline & & $1.59-1.98$ & 24 & 6.2 & 3.2 \\
\hline & & $<1.59$ & 27 & 5.5 & 3.0 \\
\hline \multirow[t]{3}{*}{2} & \multirow[t]{3}{*}{ Avg. bifurcation ratio (ABR) } & $>2.97$ & 36 & 6.2 & 3.5 \\
\hline & & $2.65-2.97$ & 8 & 5.5 & 3.2 \\
\hline & & $<2.65$ & 13 & 5.3 & 3.0 \\
\hline \multirow[t]{3}{*}{3} & \multirow[t]{3}{*}{ Avg. stream sinuosity index (ASSI) } & $>1.32$ & 21 & 5.4 & 3.5 \\
\hline & & $1.24-1.32$ & 5 & 6.2 & 4.6 \\
\hline & & $<1.24$ & 31 & 5.5 & 3.0 \\
\hline \multirow[t]{3}{*}{4} & \multirow{3}{*}{$\begin{array}{l}\text { Avg. fractal dimension of drainage } \\
\text { network (AFDDN) }\end{array}$} & $>1.95$ & 16 & 5.0 & 3.0 \\
\hline & & $1.16-1.95$ & 24 & 5.5 & 3.6 \\
\hline & & $<1.16$ & 17 & 6.2 & 3.5 \\
\hline \multirow[t]{3}{*}{5} & \multirow[t]{3}{*}{ Hierarchical anomaly index (HAI) } & $>1.90$ & 23 & 5.3 & 3.0 \\
\hline & & $1.36-1.90$ & 12 & 5.4 & 3.9 \\
\hline & & $<1.36$ & 22 & 6.2 & 3.2 \\
\hline \multirow[t]{3}{*}{6} & \multirow[t]{3}{*}{ Basin form factor (BFF) } & $>0.36$ & 36 & 6.2 & 3.5 \\
\hline & & $0.22-0.36$ & 20 & 5.5 & 3.0 \\
\hline & & $<0.22$ & 1 & 4.3 & 4.3 \\
\hline \multirow[t]{3}{*}{7} & \multirow[t]{3}{*}{ Circulatory ratio (CR) } & $>0.42$ & 27 & 5.5 & 3.2 \\
\hline & & $0.34-0.42$ & 21 & 6.2 & 3.5 \\
\hline & & $<0.34$ & 9 & 5.0 & 3.0 \\
\hline \multirow[t]{3}{*}{8} & \multirow[t]{3}{*}{ Ellipticity index (EI) } & $>3.51$ & 0 & 0.0 & 0.0 \\
\hline & & $2.18-3.51$ & 17 & 5.5 & 3.0 \\
\hline & & $<2.18$ & 40 & 6.2 & 3.5 \\
\hline \multirow[t]{3}{*}{9} & \multirow[t]{3}{*}{ Elongation ratio (ER) } & $>0.67$ & 36 & 6.2 & 3.5 \\
\hline & & $0.53-0.67$ & 20 & 5.5 & 3.0 \\
\hline & & $<0.53$ & 1 & 4.3 & 4.3 \\
\hline \multirow[t]{3}{*}{10} & \multirow[t]{3}{*}{ Fitness ratio (FR) } & $>0.37$ & 24 & 5.5 & 3.5 \\
\hline & & $0.35-0.37$ & 22 & 6.2 & 3.0 \\
\hline & & $<0.35$ & 11 & 5.3 & 3.2 \\
\hline 11 & Basin shape index (BSI) & $>2.55$ & 0 & 0.0 & 0.0 \\
\hline & & $1.61-2.55$ & 30 & 5.5 & 3.0 \\
\hline & & $<1.61$ & 27 & 6.2 & 3.5 \\
\hline 12 & Basin compactness (BC) & $>0.45$ & 3 & 5.3 & 4.5 \\
\hline & & $0.35-0.45$ & 10 & 5.5 & 4.0 \\
\hline & & $<0.35$ & 44 & 6.2 & 3.0 \\
\hline 13 & Asymmetry factor (AF) & $>0.59$ & 29 & 5.5 & 3.2 \\
\hline & & $0.45-0.59$ & 22 & 5.4 & 3.5 \\
\hline & & $<0.45$ & 6 & 6.2 & 3.0 \\
\hline 14 & Avg. transverse topographic symmetry & $>0.38$ & 15 & 6.2 & 3.9 \\
\hline & factor (ATTSF) & $0.28-0.38$ & 2 & 5.5 & 4.3 \\
\hline & & $<0.28$ & 40 & 5.5 & 3.0 \\
\hline 15 & Stream frequency (SF) & $>0.95$ & 11 & 5.5 & 4.0 \\
\hline & & $0.76-0.95$ & 45 & 6.2 & 3.0 \\
\hline & & $<0.76$ & 1 & 4.3 & 4.3 \\
\hline 16 & Drainage texture (DT) & $>0.95$ & 37 & 6.2 & 3.0 \\
\hline & & $0.25-0.95$ & 20 & 5.1 & 3.2 \\
\hline & & $<0.25$ & 0 & 0.0 & 0.0 \\
\hline 17 & Drainage density (DD) & $>1.07$ & 34 & 6.2 & 3.0 \\
\hline & & $0.80-1.07$ & 23 & 5.3 & 3.2 \\
\hline & & $<0.80$ & 0 & 0.0 & 0.0 \\
\hline
\end{tabular}


Table 6. (Continued.)

\begin{tabular}{|c|c|c|c|c|c|}
\hline $\begin{array}{l}\text { Sl. } \\
\text { no. }\end{array}$ & Parameters & Range & $\begin{array}{l}\text { No. of } \\
\text { earthquakes }\end{array}$ & $\begin{array}{l}\text { Highest } \\
\text { magnitude }\end{array}$ & $\begin{array}{l}\text { Lowest } \\
\text { magnitude }\end{array}$ \\
\hline \multirow[t]{3}{*}{18} & \multirow{3}{*}{$\begin{array}{l}\text { Hierarchical anomaly density } \\
\text { (HAD) }\end{array}$} & $>1.53$ & 23 & 5.3 & 3.0 \\
\hline & & $0.85-1.53$ & 24 & 6.2 & 3.6 \\
\hline & & $<0.85$ & 10 & 5.5 & 3.2 \\
\hline \multirow[t]{3}{*}{19} & \multirow[t]{3}{*}{ Denudation rate index (DRI) } & $>114.79$ & 11 & 5.3 & 3.0 \\
\hline & & $86.42-114.79$ & 36 & 6.2 & 3.5 \\
\hline & & $<86.42$ & 10 & 5.5 & 3.2 \\
\hline \multirow[t]{3}{*}{20} & \multirow[t]{3}{*}{ Local relief (LR) } & $>2607$ & 36 & 6.2 & 3.0 \\
\hline & & $1899-2607$ & 19 & 5.5 & 3.5 \\
\hline & & $<1899$ & 2 & 4.6 & 4.3 \\
\hline \multirow[t]{3}{*}{21} & \multirow[t]{3}{*}{ Relief ratio (RR) } & $>0.11$ & 31 & 6.2 & 3.2 \\
\hline & & $0.07-0.11$ & 24 & 5.5 & 3.0 \\
\hline & & $<0.07$ & 2 & 4.6 & 4.3 \\
\hline \multirow[t]{3}{*}{22} & \multirow[t]{3}{*}{ Dissection index (DI) } & $>0.83$ & 53 & 6.2 & 3.0 \\
\hline & & $0.68-0.83$ & 3 & 4.5 & 4.4 \\
\hline & & $<0.68$ & 1 & 4.6 & 4.6 \\
\hline \multirow[t]{3}{*}{23} & \multirow[t]{3}{*}{ Ruggedness index (RI) } & $>2.80$ & 36 & 6.2 & 3.0 \\
\hline & & $1.62-2.80$ & 20 & 5.5 & 3.5 \\
\hline & & $<1.62$ & 1 & 4.3 & 4.3 \\
\hline \multirow[t]{3}{*}{24} & \multirow{3}{*}{$\begin{array}{l}\text { Avg. stream length gradient index } \\
\text { (ASLGI) }\end{array}$} & $>755.22$ & 22 & 6.2 & 3.2 \\
\hline & & $328.52-755.22$ & 11 & 5.3 & 4.0 \\
\hline & & $<328.52$ & 24 & 5.5 & 3.0 \\
\hline \multirow[t]{3}{*}{25} & \multirow[t]{3}{*}{ Hypsometric integral (HI) } & $>0.53$ & 33 & 6.2 & 3.2 \\
\hline & & $0.32-0.53$ & 23 & 5.3 & 3.0 \\
\hline & & $<0.32$ & 1 & 4.3 & 4.3 \\
\hline \multirow[t]{3}{*}{26} & \multirow{3}{*}{$\begin{array}{l}\text { Avg. valley-floor width-height ratio } \\
\text { (AVFWHR) }\end{array}$} & $>21.61$ & 0 & 0.0 & 0.0 \\
\hline & & $14.21-21.61$ & 1 & 4.3 & 4.3 \\
\hline & & $<14.21$ & 56 & 6.2 & 3.0 \\
\hline \multirow[t]{3}{*}{27} & \multirow[t]{3}{*}{ Landscape roughness index (LRI) } & $>0.72$ & 12 & 6.2 & 4.0 \\
\hline & & $0.34-0.72$ & 44 & 5.5 & 3.0 \\
\hline & & $<0.34$ & 1 & 4.3 & 4.3 \\
\hline
\end{tabular}

quantitative indices are grouped into three classes, namely, high, medium and low indexed values which have been intersecting with seismic frequency and magnitude (figure 13 and table 6). Also, the seismotectonic features and earthquake epicentres have been overlaid on the ASTER DEMderived $3 \mathrm{D}$ view and satellite images (figure 14a and $\mathrm{b}$ ). The result shows that the higher index value of $\mathrm{ABR}$ and HAI shows a higher frequency of earthquake (36 and 23) with significant highest (6.2 and 5.3) and lowest (3.5 and 3.0) earthquake magnitudes, respectively. The drainage bifurcation and anomalous drainage network signifies the significant structural control on the drainage network which may be further influenced by fold-thrust movements which are probable factors for past earthquakes in the greater and Lesser Himalayan regions (Bahrami 2013; Shukla et al. 2014). A higher value of FR represents 24 earthquake epicentres where the highest and the lowest magnitudes are 5.5 and 3.5 , respectively. The anomaly in drainage adjustment occurs when a higher length of stream has been adjusted in a narrow basin which may be compressed from a wider basin due to active thrust movement which is an important factor for past earthquakes in the Himalayan frontal surface. Also, higher values of DD, HAD and DT shows a higher frequency of the earthquake epicentre $(34,23$ and 37$)$ with the highest magnitude of earthquake $(6.2,5.3$ and 6.2) in the study area. The narrow steep valley in the high resistance surface and the heterogeneous undulating topography which is produced due to the active thrust movement in the crystalline Greater Himalayan complex and Lesser Himalayan older folded cover sequence are relevant factors for earthquakes in 
the study region (Gioia et al. 2011; Thomas et al. 2012; Shukla et al. 2014). A high indexed value of LR, RR, DI, RI and HI also shows a higher frequency of earthquake (more than 30 earthquakes) with significant magnitude $(>6.0)$. The asymmetric drainage distribution in the high resistance steep and the rough topographic surface in the Greater Himalayan terrain is produced due to the active movement of MCT and MBT (Thomas et al. 2012). Also, the high rate of relief dissection is associated with the sudden changes of slope in the mountain frontal surface due to the active tectonic movement of the MFT which is responsible for the earthquake occurrences in the past. The youthful topographic surface reflects less erosion in a high-resistance rock, indicating high tectonic activity which is another important factor for the higher frequency with the higher magnitude of earthquakes in the Greater Himalayan sequence (Keller and Pinter 2002; Altin 2012; Mahmood and Gloaguen 2012).

Similarly, a lower index value of the specific indices can signify high tectonic potentiality for earthquake occurrences. The lower index value of AVFHWR represents a higher frequency of earthquake (56) with a higher value of earthquake magnitude (6.2) while the AFDDN shows a higher frequency of earthquake (6.2) with less frequency (17). The 'v'-shaped valley in the steep resistance surface is produced due to the active MCT movement which is responsible for the higher frequency and higher magnitude earthquakes in the Greater and Lesser Himalayan sequence while neotectonic deformation on the crystalline surface causes less frequent earthquakes with a higher magnitude. Nakata (1989) and Thakur (2013) showed that the mountain frontal thrusts are marked as the displacement zone where tectonic stress on drainage is reasonable for seismic activity.

Sometimes, higher and lower index values of morphometric indices similarly show a higher tectonic influence on earthquake occurrences. A higher index value of AF shows a higher frequency of earthquake (29) while a lower index value represents a higher earthquake magnitude (6.2), indicating the tectonic tilt to the left and the right sides are both equally significant for past earthquake occurrences. Similarly, higher and lower values of ASSI show a higher frequency of earthquakes (21 and 31, respectively). The higher values of ASSI indicate the presence of compressed meanders in uplifted surfaces due to a higher strain of active thrust, while relatively lower ASSI, indicate the presence of a linear fracture in the sub-surface which are both responsible for increasing the frequency of earthquakes in the study region (Litchfield et al. 2003). The antifoam represents a major folded structure which is formed in the Ranjit window zone along the Great Rangit river and mountain frontal zone along the Tista river where the high-meandering channel pattern of the Rangit river coincides with the frequency of earthquake occurrences (Mrinalinee Devi et al. 2016). Even the structural patterns are quite complex within the windows because of the repetition of geological formation and the presence of many fractures/faults due to consequent thrusting (Mitra et al. 2010). The seismotectonic study in the Sikkim-Darjeeling Himalaya indicates that the TL which is extended in the central part of the study region around the central thrust zone has a greater influence on earthquake occurrences (Mukul et al. 2014). The higher and lower values of the ASLGI represent 22 and 24 earthquake frequencies with significant magnitudes of 6.2 and 5.5, respectively. The presence of high-resistant hard rocks in the Greater and Lesser Himalayan sequences indicates high tectonic activity and produces significant earthquake magnitude (Keller and Pinter 2002; Mahmood and Gloaguen 2012) while the presence of strike-slip fault is also responsible for significant earthquake (Keller and Pinter 2002; Mahmood and Gloaguen 2012). The deep hypocentres of earthquakes with higher magnitudes are reported in the Greater and Lesser Himalayan sequence which is highly responsible for the displacement of the existing fault and the subsequent earthquake. The previous seismotectonic study also showed that the distribution of earthquakes has a deep hypocentral distance and can extend towards the Gangtok lineament (Mukul et al. 2014).

The moderate index value of morphometric indices also shows significant frequency and magnitude of earthquakes. The moderate values of ASLR, DRI, AFDDN, SF and LRI show an earthquake frequency of $24,36,24,45$ and 44 , respectively, with significant highest magnitude ranges between 5.5 and 6.2. The presence of high erosional potential hard resistance rock in the greater crystalline complex, the high rate of weathering in the lesser and Siwalik Himalayan sequence, neotectonic deformation and forms of alluvial terraces in the quaternary surface, undulating rough topography in the Greater and Lesser Himalayan surface and structural features controlling the drainage network are indicators of tectonic activity 

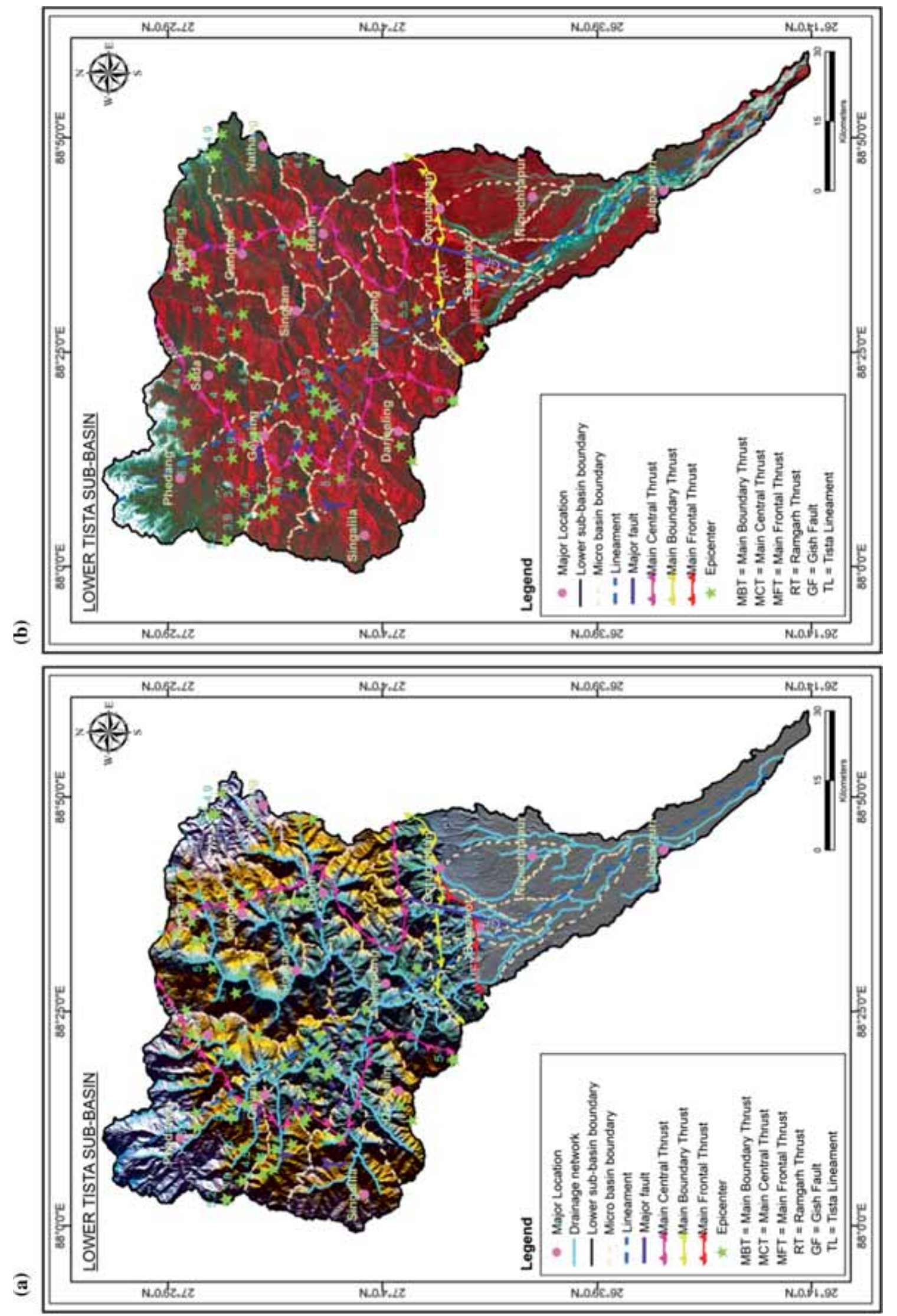

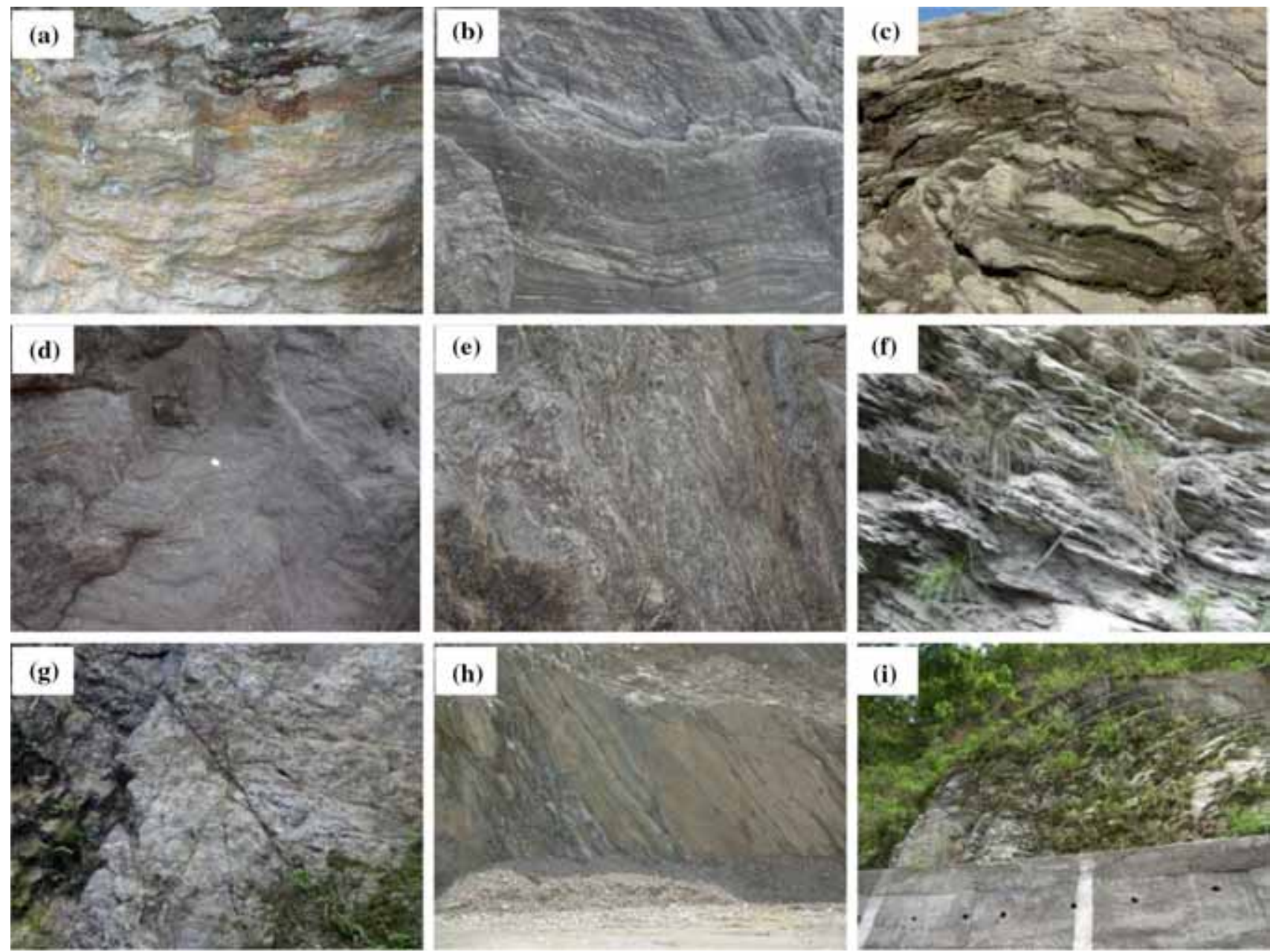

Figure 15. Morphostructural evidences: (a) Schistose rock with faulted structure in the Greater Himalayan sequence, (b) thrust fault with a folded structure, (c) thrust fault with a fracture in the Greater Himalayan sequence, (d) a folded structure in the gneissic rock, (e) micro fold in the gneissic rock with a fracture near the rock garden region - Darjeeling, (f) micro fractures in the Lesser Himalayan sequence, (g) crisscross fractures in hard rocks in the Lesser Himalayan sequence, (h) angular and parallel lineament/fractures in the Siwalik group of rocks and (i) nappe/overthrust in the Siwalik sequence near Sevoke.

responsible for past earthquake occurrences in the study region.

The study also indicates that the geometry of the basin shape such as lower values of BFF, $\mathrm{CR}$ and ER and higher values of $\mathrm{EI}$ and BSI indicate a more elongated basin which has a greater influence on tectonic activity. Also, a lower value of ASLGI and ASSI in the linear micro basins signifies the presence of a strike-slip fault and a linear fracture or lineament which are the significant causes of earthquakes. Dasgupta et al. (2013) show that the strike-slip faults are associated with the earthquake epicentres in the foothill zones. TL is the counterpart of the basement fault crossing the MCT, MBT and MFT at various places along the Tista and Rangit river basins (Dasgupta et al. 1987). This transverse lineament produces a seismotectonically active zone in the Himalayan frontal surface where the drainage pattern and the geometric basin shape anomaly are recognised (Dasgupta et al. 2013). Mukul (2000) reveals that the terrace upliftment is the result of the reactivation of the MBT in the Siwalik surface and foreland propagation of the frontal thrust along the Tista river valley. The more elongated and linear micro basin is located in the Quaternary surface in the study region that has not even produced any significant earthquake in the past has been observed in figure 14( $\mathrm{a}$ and $\mathrm{b})$. Geomorphic and neotectonic deformation indicating faulting along the range and outboard of the range front in the alluvial surface have been recognised by Nakata (1972, 1989). Also, the truncated terrace along 
the fault in the alluvial surface indicates tectonic displacement where tectonic tilt, landscape roughness and significant drainage anomaly are recognised by analysing the morphometric parameters (Mukul 2000). The dislocation of the strike-slip Gish transverse fault was recognised by the GPS measurement between the Gish and the Chel river micro basin where the tectonic tilt is significant (Mukul et al. 2014).

The morphological parameters have a significant relationship with the morphostructural features. The drainage basins of the Himalayan region have been evolved during different geological periods due to tectonic movements. Such tectonic influence in the regional extent formed their distinctive tectonic-stratigraphic features, namely, folding, faulting and lineament structure (McCann and Saintot 2003). Schistose rock with faulted structures has been observed in the Greater Himalayan sequence (figure 15a). Similarly, thrust fault with a folded structure and thrust fault with a fracture have been recognised in the Greater Himalayan sequence (figure $15 \mathrm{~b}$ and c). Micro folds in gneissic rock with fractures have been found on the crystalline surface (figure $15 \mathrm{~d}$ and e). The Lesser and Greater Himalaya is segregated by the MCT thrust. The anomaly in drainage pattern, drainage bifurcation, drainage compression, steepness of relief and resistance surface topography has been evolved with the influence of the MCT thrust. Micro fractures are recognised in the Lesser Himalayan sequence, and Crisscross fractures are observed in hard rocks indicating the release of rock strain due to seismotectonic activity (figure $15 \mathrm{f}$ and $\mathrm{g}$ ). The Ramgharh thrust (RT) included in the Lesser Himalayan sequence (Grujic et al. 2002; Mukul et al. 2014) has a great influence on drainage morphology. It mostly covers the Rangit river basin, covering the thrust zone named as the Rangit window (Mottram et al. 2014). Folded domal structures have been identified in the southern part of the study area around the Rangit window. It is observed that the faulted zone is associated with the rocks of the underlying Lachi formation. The granite-gneiss formation is affected by a series of faults and graphite schists are also observed along the shear or the fault plane. The changes in the drainage hierarchical order, drainage compression, basin shape and drainage basin asymmetry occurred due to the influence of the Ramgarh thrust. The presence of a fault in this region changes the geological succession and a repetition of the same formation has also been recognised which are both responsible for the evolution of the channel pattern. Angular and parallel lineament/fractures and folded structures in the Siwalik group of rocks are very common which are due to the active tectonic movement along the MBT and the MFT (figure $15 \mathrm{~h}$ and i). Neotectonic deformation, tilted topography and drainage migration have occurred due to the movement of the frontal thrust and the upliftment of the land surface, also leading to a drainage pattern evaluation which changed from a linear to a wider valley. The quaternary surface also has a resemblance with lineament, fractures and fault scarp which have a greater influence on geomorphometric anomaly and its evolution.

\section{Conclusion}

Quantitative databases have been generated for various drainage morphometric parameters and a comparative analysis has been carried out between the parameters. Also, the parameters have been integrated with previous seismological databases to assess their significance and impact on seismotectonic activity. The result shows that the higher index value of ABR, HAI, FR, DD, HAD, DT, LR, RR, DI, RI and HI shows a higher frequency earthquake ranging between 23 and 36 with the significantly highest earthquake magnitude varying between 5.3 and 6.2 and the lowest magnitude differing between 3.0 and 3.5. The drainage bifurcation and anomalous drainage network, drainage adjustment anomaly in a micro basin along the mountain front, a narrow steep valley in the high-resistance surface with heterogeneous undulating topography in the crystalline Greater Himalayan complex as well as the Lesser Himalayan older folded cover sequence and the asymmetric drainage distribution due to the effect of an active thrust movement are probable factors for the previous earthquakes in the Himalayan region. The lower indexed values of AVFHWR and AFDDN indicate higher magnitude earthquake while the same indexed values of AVFHWR and AFDDN represent high and low frequency (56 and 17), respectively. The 'v' shaped valley in the steep resistance surface is produced due to the active MCT movement between the Greater and the Lesser Himalayan sequence where higher earthquake frequencies and magnitudes are recognised. Similarly, it is observed that the neotectonic deformation in the crystalline surface produces less 
frequency with a higher earthquake magnitude. Higher and lower indexed values of AF represent a higher earthquake frequency (29) with a high earthquake magnitude (6.2), indicating the tectonic tilt in the left and the right side are both equivalently significant for past earthquake occurrences. Similarly, higher and lower values of ASSI indicate a higher frequency of earthquake (21 and 31 , respectively, revealing the presence of compressed meanders in the uplifted surface due to a higher strain of active thrust and the presence of a linear fracture in the sub-surface which are both responsible for increasing the frequency of the earthquake in the study region. The study also indicates that the geometry of the basin shape, with lower values of BFF, CR and ER and higher values of $\mathrm{EI}$ and $\mathrm{BSI}$, reveals a more elongated basin which has a greater influence on tectonic activity. Also, a lower value of ASLGI and ASSI in the linear micro basin signifies the presence of a strike-slip fault and a linear fracture or lineament which are significant sources of earthquakes. It can also be observed that the elongated and linear micro basin is located in the Quaternary surface in the study region which has not produced any significant earthquakes in the past. The study concludes that the geomorphometric anomaly is an important parameter for seismotectonic activity. In the context of future work, it can be stated that the parameters will be selected for active tectonic study based on the correlation. The AHP method will be applied for the development of the active tectonic index. Similarly, PCA can also be performed to prioritise the parameters for the estimation of the active tectonic index. This study is a precursor to future seismic hazard assessment studies.

\section{Acknowledgements}

The authors would like to thank the reviewers and the editor for their suggestions and critical reviews. The authors are also thankful to SRM Institute of Science and Technology sponsored Pilot Research on Selective Excellence programme for providing all necessary facilities and constant encouragement for doing this research work.

\section{References}

Abrahams A D 1984 Channel networks: A geomorphological perspective; Water Resour. Res. 20 161-168.
Altin T B 2012 Geomorphic signatures of active tectonic in drainage basins in the southern Bolkar mountain Turkey; J. Indian Soc. Remote Sens. 40(2) 271-285.

Anbazhagan P and Sitharam T G 2008 Seismic microzonation of Bangalore, India; J. Earth Syst. Sci. $117833^{-}$ 852.

Asthana A K L, Gupta A K, Luirei K, Bartarya S K, Rai S K and Tiwari S K 2015 A quantitative analysis of the Ramganga drainage basin and structural control on drainage pattern in the fault zones, Uttarakhand; J. Geol. 86 9-22.

Avena G C, Giuliano G and Lupia Palmieri E 1967 Sulla valutazione quantitativa della gerarchizzazione ed evoluzione dei reticoli fluviali; Boll. Soc. Geol. Ital. 86 781-796.

Bahrami S 2013 Analyzing the drainage system anomaly of Zagros basins: Implications for active tectonics; Tectonophys. 608 914-928.

Bali R, Agrawal K K and Ali S N 2012 Drainage morphometry of Himalayan Glacio-fluvial basin, India: Hydrologic and neotectonic implication; Environ. Earth Sci. 66(4) 1163-1174.

Bansal B K and Nath S K 2011 Seismic microzonation handbook; Geoscience divisions, Ministry of Earth Sciences, Government of India, New Delhi.

Bansal B K and Vandana C 2007 Microzonation studies in India: DST initiatives; In: Proceedings of workshop on Microzonation, Indian Institute of Science, Bangalore, pp. 1-6.

Barbera P L and Rosso R 1989 On the fractal dimension of stream network; Water Resour. Res. 25(4) 735-741.

Bhatt C M, Litoria P K and Sharma P K 2008 Geomorphic signatures of active tectonics in Bist Doab interfluvial tract of Punjab, NW India; J. Indian Soc. Remote Sens. 36 361-373.

Bhatta B 2008 Remote sensing and GIS; Oxford University Press, New Delhi.

Bhattacharya F, Rastogi B K and Kothyai G C 2013 Morphometric evidence of seismicity around Wagad and Gedi faults, eastern Kachchh, Gujarat; J. Geol. 81 113-121.

Bishop P 2007 Long-term landscape evolution: Linking tectonics and surface processes; Earth Surf. Proc. Land. 32 329-365.

Bull W B and McFadden L D 1977 Tectonic geomorphology north and south of the Garlock fault, California; In: Geomorphology in arid regions, Proceedings at the eighth annual geomorphology symposium (ed.) Doehering D O, State University of New York, Binghamton, NY, pp. 115138.

Chorley R J 1969 The drainage basin as the fundamental geomorphic unit; In: Water, earth and man (ed.) Chorley R J, Methuen and Co Ltd., London, 588p.

Ciccacci S, Fredi P, Lupia Palmieri E and Pugliese F 1980 Contributo dell'analisi geomorfica quantitativa alla valutazione dell'entitàdell'erosione nei bacini fluviali; Boll. Soc. Geol. Ital. 99 455-516.

Clarke J I 1970 Morphometry from maps; In: Essays in geomorphology dury (ed.) Heineman G H, Elsevier Publ. Co., London, pp. 235-274.

Cox R T 1994 Analysis of drainage-basin symmetry as a rapid technique to identify areas of possible quaternary tilt-block tectonics: An example from the Mississippi embayment; Geol. Soc. Am. Bull. 106(5) 571-581. 
Cuong N Q and Zuchiewicz W A 2001 Morphotectonic properties of the Lo river fault near Tam Dao in north Vietnam; Nat. Hazards Earth Syst. Sci. 1 15-22.

Dasgupta S, Mukhopadhyay M and Nandy D R 1987 Active transverse features in the central portions of the Himalaya; Tectonophys. 136 255-264.

Dasgupta S, Pande P, Ganguly D, Iqbal Z, Sanyal K, Venkataraman N V, Sural B, Harendranath L, Mazumdar K, Sanyal S, Roy A, Das L K, Misra P S and Gupta H K 2000 Seismotectonic atlas of India and its environs (eds) Narula P L, Acharyya S K and Banerjee J, Special Publication Geological Survey of India, Calcutta, 86p.

Dasgupta S, Mukhopadhyay B, Mukhopadhyay $M$ and Nandy D R 2013 Role of transverse tectonics in the Himalayan collision: Further evidences from two contemporary earthquakes; J. Geol. 81 241-247.

Deffontaines B and Chorowicz J 1991 Principles of drainage basin analysis from multisource data: Application to the structural analysis of the Zaire Basin; Tectonophys. 194(3) 237-263.

Dombradi E, Timar G, Bada G, Cloetingh S and Frank Horvath F 2007 Fractal dimension estimations of drainage network in the Carpathian-Pannonian system; Global Planet Change 58 197-213.

Duarah B P and Phukan S 2011 Seismic hazard assessment in the Jia Bhareli river catchment in eastern Himalaya from SRTM-derived basin parameters, India; Nat. Hazards $\mathbf{5 9}$ $367-381$.

El Hamdouni R, Irigaray C, Fernandez T, Chacon J and Keller E A 2008 Assessment of relative active tectonics, southwest border of Sierra Nevada (southern Spain); Geomorphology 96 150-173.

Ferry M, Meghraoui M, AbouKaraki N, Al-Taj M, Amoush H, Al-Dhaisat S and Barjous M 2007 A 48-kyr-long slip rate history for the Jordan Valley segment of the Dead Sea Fault; Earth Planet. Sci. Lett. 260 394-406.

Gioia D, Martino C and Schiattarella M 2011 Long- to short-term denudation rates in the southern Apennines: Geomorphological markers and chronological constraints; Geol. Carpathica 62 27-41.

Grujic D, Hollister L S and Parrish R R 2002 Himalayan metamorphic sequence as an orogenic channel: Insight from Bhutan; Earth Planet Sci. Lett. 198 177-191.

Hack J T 1973 Stream profile analysis and stream-gradient index; J. Res. US Geol. Surv. 1 421-429.

Hare P H and Gardner T W 1985 Geomorphic indicators of vertical neotectonism along converging plate margins, Nicoya Peninsula, Costa Rica; In: Tectonic geomorphology (eds) Morisawa M and Hack J T, Allen and Unwin, Boston, pp. 75-104.

Hassen M B, Deffontaines B and Turki M M 2014 Recent tectonic activity of the Gafsa fault through morphometric analysis: Southern atlas of Tunisia; Quat. Int. 338 99-112.

Horton R E 1932 Drainage basin characteristics; Trans. Am. Geophys. Union 13 350-361.

Horton R E 1945 Erosional development of streams and their drainage basins; Bull. Geol. Soc. Am. 56 275-370.

Howard A D 1967 Drainage analysis in geologic interpretation: A summation; Am. Assoc. Petrol. Geol. Bull. 51 2246-3428.

John B and Rajendran C P 2008 Geomorphic indicators of neotectonism from the precambrian terrain of peninsular
India: A study from the Bharathapuzha basin, Kerala; J. Geol. $71827-840$.

Kaliraj S, Chandrasekar N and Magesh S 2015 Morphometric analysis of the river Thamirabarani sub-basin in Kanyakumari district, south west coast of Tamil Nadu, India, using remote sensing and GIS; Environ. Earth Sci. 73 $7375-7401$.

Keller E A and Pinter N 2002 Active tectonics. Earthquakes, uplift, and landscape; Prentice Hall, New Jersey,break 362p.

Kuk V, Prelogovi E and Dragieevic I 2000 Seismotectonically active zones in the dinarides; Geol. Croat. 53/2 295303.

Litchfield N J, Campbell J K and Nicol A 2003 Recognition of active reverse faults and folds in North Canterbury, New Zealand, using structural mapping and geomorphic analysis; New Zeal. J. Geol. Geophys. 46(4) 563579.

Lo C P and Yeung A K W 2007 Concepts and Techniques of Geographic Information System, Upper Saddle River, NJ: Prentice Hall.

Mahmood S A and Gloaguen R 2012 Appraisal of active tectonics in Hindu Kush: Insights from DEM derived geomorphic indices and drainage analysis; Geosci. Front. 3(4) 407-428.

McCann T and Saintot A 2003 Tracing tectonic deformation using the sedimentary record; Geol. Soc. London, Spec. Publ. 208 1-28.

Melton M A 1957 An analysis of the relations among elements of climate, surface properties and geomorphology; Columbia University, New York, NY, USA.

Miller V C 1953 A quantitative geomorphic study of drainage basin characteristics in the Clinch Mountain area, Virginia and Tennessee, Naval Research Project 389-042, Technical Report, 3, Columbia University.

Mitra G, Bhattacharyya K and Mukul M 2010 The Lesser Himalayan Duplex in Sikkim: Implications for variations in Himalayan shortening; J. Geol. 75 289301.

Mottram C M, Argles T W, Haris N B W, Parish R R, Horstwod M S A, Waren C J and Gupta S 2014 Tectonic interleaving along the Main Central Thrust, Sikkim Himalaya; J. Geol. Soc. London 171 255-268.

Mrinalinee Devi R K, Bhakuni S S, Phukan M K and Duarah R 2016 Tectonic forcing of drainages and geomorphic features developed across Himalayan mountain frontal part of western limb of Siang Antiform, Arunachal Himalaya; Environ. Earth Sci. 75 413, https://doi.org/ 10.1007/s12665-015-5081-4.

Mukherjee A and Sharma P K 2013 Geology and mineral resources of West Bengal; Report; Geological Survey of India, West Bengal, Kolkata.

Mukul M 2000 The geometry and kinematics of the main boundary thrust and related neotectonics in the Darjiling Himalayan fold and- thrust belt, West Bengal India; J. Struct. Geol. 22 1261-1283.

Mukul M, Sridevi Jade S, Ansari K and Abdul Matin A 2014 Seismotectonic implications of strike-slip earthquakes in the Darjiling-Sikkim Himalaya; Curr. Sci. India 106 $198-210$.

Musumeci G, Ribolini A and Spagnolo M 2003 The effects of late Alpine tectonics in the morphology of the Argentera 
Massif (Western Alps, Italy-France); Quat. Int. 102 191201.

Nakata T 1972 Geomorphic history and crustal movements of foothills of the Himalaya; Inst. of Geography, Tohoku Univ., Sendai, 77p.

Nakata T 1989 Active faults of the Himalaya of India and Nepal; Geol. Soc. Am. Spec. Paper 232 243-264.

Nath S K, Pal I, Shukla K, Pal D K, Raj A, Thingbaijam K S and Bansal B K 2007 Earthquake hazard zonation of Sikkim Himalaya using a GIS platform; Nat. Hazards 45 333-377.

Nir D 1957 The ratio of relative and absolute altitude of Mt. Carmel; Geogr. Rev. 27 564-569.

Ozdemir H and Bird D 2009 Evaluation of morphometric parameters of drainage networks derived from topographic maps and DEM in point of floods; Environ. Geol. 56 1405-1415.

Pal I, Nath S K, Shukla K, Pal D K, Raj A, Thingbaijam K K S and Bansal B K 2008 Earthquake hazard zonation of Sikkim Himalaya using a GIS platform; Nat. Hazards $\mathbf{4 5}$ 333-377.

Panek T 2004 The use of morphometric parameters in tectonic geomorphology (on the example of the Western Beskydy Mts); Geographica 1 111-126.

Perez-Pena J V, Azor A, Azanon J M and Keller E A 2010 Active tectonics in the Sierra Nevada (Betic Cordillera, SE Spain): Insights from geomorphic indexes and drainage pattern analysis; Geomorphology 119 74-87.

Prabu P and Baskaran R 2013 Drainage morphometry of upper Vaigai river Sub-basin, Western Ghats, south India using remote sensing and GIS; J. Geol. 82 519-528.

Ramírez-Herrera M T 1998 Geomorphic assessment of active tectonics in the Acambay Graben, Mexican Volcanic Belt; Earth Surf. Process. 23 317-332.

Reddy G P O, Maji A K and Gajbhiye K S 2004 Drainage morphometry and its influence on landform characteristics in a basaltic terrain, Central India - A remote sensing and GIS approach; Int. J. Appl. Earth Obs. Geoinf. 6(1) 1-16.

Sarkar S S, Ali M A and Bhattacharya G 2012 Geology and mineral resources of Sikkim, report; Geological Survey of India, West Bengal, Kolkata.

Sarma J N, Acharjee S and Murgante B 2015 Morphotectonic study of the Brahmaputra basin using geoinformatics; J. Geol. 86 324-330.

Schumm S A 1956 The evolution of drainage system and slopes in badlands at Perth Amboy, New Jersey; Bull. Geol. Soc. Am. 67 597-646.

Shukla D P, Dubey C S, Ningreichon A S, Singh R P, Mishra B K and Singh S K 2014 GIS-based morpho-tectonic studies of Alaknanda river basin: A precursor for hazard zonation; Nat. Hazards 71 1433-1452.
Silva P G, Goy J L, Zazo C and Bardaj T 2003 Faultgenerated mountain fronts in southeast Spain: Geomorphologic assessment of tectonic and seismic activity; Geomorphology 50 203-225.

Singh S 2005 Geomorphology; Prayag Pustak Bhawan, Allahabad, India.

Singh Y, Biju John B, Ganapathy G P, George A, Harisanth S, Divyalakshmi K S and Kesavan S 2016 Geomorphic observations from southwestern terminus of Palghat Gap, south India and their tectonic implications; J. Earth Syst. Sci. 125(4) 821-839.

Stoddart D R 1969 Climatic geomorphology in water earth, and man (ed.) Chorley R J, Methen and Co. Ltd., pp. 473-485.

Strahler A N 1952 Hypsometric (area-altitude) analysis of erosional topography; Geol. Soc. Am. Bull. 63 11171142 .

Thakur V C 2013 Active tectonics of Himalayan Frontal fault system; Int. J. Earth Sci. (Geol. Rundsch) 102 17911810 .

Thomas J, Joseph S and Thrivikramaji K P et al. 2012 Morphometric aspects of a small tropical mountain river system, the southern Western Ghats, India; Environ. Earth Sci. 66 2353-2366.

Tsodulos I M, Koukouvelas I K and Pavlides S 2008 Tectonic geomorphology of the easternmost extension of the Gulf of Corinth (Beotia, Central Greece); Tectonophys. 453 211232.

Venkatesan A, Jothibasu A, Anbazhagan S 2015 GIS based quantitative geomorphic analysis of fluvial system and implications on the effectiveness of river basin environmental management; In: Environmental management of river basin ecosystems (eds) Ramkumar M et al., Springer, Earth Syst. Sci., https://doi.org/10.1007/ 978-3-319-13425-3_11.

Verma M and Bansal B K 2013 Seismic hazard assessment and mitigation in India: An overview; Int. J. Earth Sci. (Geol. Rundsch) $102 \quad 1203-$ 1218 .

Viveen W, Balen R T, Schoorl J M, Veldkamp A, Temme A J A M and Vidal-Romani J R 2012 Assessment of recent tectonic activity on the NW Iberian Atlantic margin by means of geomorphic indices and field studies of the lower Miño river terraces; Tectonophys. 544-545 $13-30$.

Zavoianu I 1985 Morphometry of drainage basins; Institute of Geography, Bucharest.

Zuchiewicz W 1989 Morphotectonic phenomena in the Polish Flysch Carpathians: A case study of the eastern Beskid Niski mountains; Questiones Geographicae 15(2) Special Issue, pp. 155-167. 